Article

\title{
Partial Fluxes of Phosphoric Acid Anions through Anion-Exchange Membranes in the Course of $\mathrm{NaH}_{2} \mathrm{PO}_{4}$ Solution Electrodialysis
}

\author{
Olesya Rybalkina, Kseniya Tsygurina, Ekaterina Melnikova, Semyon Mareev, Ilya Moroz, \\ Victor Nikonenko *(D) and Natalia Pismenskaya
}

Kuban State University, 149 Stavropolskaya st., 350040 Krasnodar, Russia

* Correspondence: v_nikonenko@mail.ru; Tel.: +7-918-41-45-816

Received: 2 July 2019; Accepted: 19 July 2019; Published: 23 July 2019

\begin{abstract}
Electrodialysis (ED) with ion-exchange membranes is a promising method for the extraction of phosphates from municipal and other wastewater in order to obtain cheap mineral fertilizers. Phosphorus is transported through an anion-exchange membrane (AEM) by anions of phosphoric acid. However, which phosphoric acid anions carry the phosphorus in the membrane and the boundary solution, that is, the mechanism of phosphorus transport, is not yet clear. Some authors report an unexpectedly low current efficiency of this process and high energy consumption. In this paper, we report the partial currents of $\mathrm{H}_{2} \mathrm{PO}_{4}{ }^{-}, \mathrm{HPO}_{4}{ }^{2-}$, and $\mathrm{PO}_{4}{ }^{3-}$ through Neosepta $\mathrm{AMX}$ and Fujifilm AEM Type $\mathrm{X}$ membranes, as well as the partial currents of $\mathrm{H}_{2} \mathrm{PO}_{4}{ }^{-}$and $\mathrm{H}^{+}$ions through a depleted diffusion layer of a $0.02 \mathrm{M} \mathrm{NaH}_{2} \mathrm{PO}_{4}$ feed solution measured as functions of the applied potential difference across the membrane under study. It was shown that the fraction of the current transported by anions through AEMs depend on the total current density/potential difference. This was due to the fact that the $\mathrm{pH}$ of the internal solution in the membrane increases with the growing current due to the increasing concentration polarization (a lower electrolyte concentration at the membrane surface leads to higher $\mathrm{pH}$ shift in the membrane). The $\mathrm{HPO}_{4}{ }^{2-}$ ions contributed to the charge transfer even when a low current passed through the membrane; with an increasing current, the contribution of the $\mathrm{HPO}_{4}{ }^{2-}$ ions grew, and when the current was about $2.5 i_{\text {lim }}{ }^{\mathrm{Lev}}\left(i_{\mathrm{lim}}{ }^{\mathrm{Lev}}\right.$ was the theoretical limiting current density), the $\mathrm{PO}_{4}{ }^{3-}$ ions started to carry the charge through the membrane. However, in the feed solution, the $\mathrm{pH}$ was 4.6 and only $\mathrm{H}_{2} \mathrm{PO}_{4}{ }^{-}$ions were present. When $\mathrm{H}_{2} \mathrm{PO}_{4}{ }^{-}$ ions entered the membrane, a part of them transformed into doubly and triply charged anions; the $\mathrm{H}^{+}$ions were released in this transformation and returned to the depleted diffusion layer. Thus, the phosphorus total flux, $j_{\mathrm{P}}$ (equal to the sum of the fluxes of all phosphorus-bearing species) was limited by the $\mathrm{H}_{2} \mathrm{PO}_{4}{ }^{-}$transport from the bulk of feed solution to the membrane surface. The value of $j_{\mathrm{P}}$ was close to $i_{\lim }{ }^{\mathrm{Lev}} / F$ ( $F$ is the Faraday constant). A slight excess of $j_{\mathrm{P}}$ over $i_{\lim }{ }^{\mathrm{Lev}} / F$ was observed, which is due to the electroconvection and exaltation effects. The visualization showed that electroconvection in the studied systems was essentially weaker than in systems with strong electrolytes, such as $\mathrm{NaCl}$.
\end{abstract}

Keywords: ion-exchange membrane; Fujifilm; Neosepta; phosphate transport; limiting current density; voltammetry

\section{Introduction}

Ampholytes are substances which have chemical structures and electrical charges that depend on the $\mathrm{pH}$ of the medium due to their participation in protonation-deprotonation reactions. Ampholytes comprise a large number of substances, including nutrients or valuable components of food. Among them there are peptides, amino acids, anthocyanins, orthophosphoric, tartaric, citric acid anions, etc. 
Electrophoresis and electrodialysis with ion-exchange membranes (IEMs) are used increasingly to extract these substances from wastewater [1-4], products of biomass processing [5], as well as liquid wastes in the food industry [6-11].

The attractiveness of these methods is conditioned by the possibility of using not only the difference in particle mobility, but also the ability to change the sign and magnitude of their electric charge when adjusting the $\mathrm{pH}$. The peculiarity of electrodialysis processes is that the composition of the ampholyte-containing solution changes in space and time not only quantitatively, as in the case of strong electrolytes, but also qualitatively. Indeed, the electrodialysis of strong electrolytes (for example, $\mathrm{NaCl}$ ) is accompanied only by an increase or decrease in their concentration [12]. In the case of ampholytes, the transformation of one form into another takes place not only in the solution, which is located in the intermembrane space [13,14], but also inside an IEM $[15,16]$. In over-limiting current regimes, generation of $\mathrm{H}^{+}$and $\mathrm{OH}^{-}$ions in protonation-deprotonation reactions with the participation of fixed groups at the membrane/depleted solution boundary $[17,18]$ can significantly affect this transformation. These reactions can cause the so-called barrier effect [19,20]. It lies in the fact that a change in the $\mathrm{pH}$ of an ampholyte-containing solution at the membrane surface facing the desalination compartment entails the transformation of ampholyte species. Depending on the value of $\mathrm{pH}$ change, the ampholyte ions, which migrate from the solution bulk towards the membrane as counterions, can turn into molecular (zwitterionic for amino acid) form or into a co-ion whose charge sign is opposite to the charge sign of the ampholyte particles in the bulk solution. The molecular (zwitterionic) form cannot be transported through the IEM at the same rate as the counterions; the coions are ejected by the electric field from the near-membrane region into the bulk solution. If the generation of $\mathrm{H}^{+}$and $\mathrm{OH}^{-}$ions occurs at both membranes forming the desalination channel, the ampholyte cations, which are formed at the anion-exchange membrane (AEM) are delivered by the electric field to the cation-exchange membrane (CEM), where they are transformed into anions and return back to the AEM, where they change the charge sign again. This phenomenon is called the circulation effect [21]. Both effects are used for the purification of amino acids or carboxylic acids from mineral impurities [22], as well as for the separation of inorganic ampholytes, such as sulfates and phosphates [23].

The transformation of an ampholyte from one form to another is also possible when it enters or leaves the membrane. This is due to the fact that the internal solution of AEM is more alkaline than the external solution; the $\mathrm{pH}$ of the internal solution is one or two units higher than in that of the external solution [16,24-26]. The reason is that the $\mathrm{H}^{+}$ions are pushed out from an AEM as coions. Similarly, due to the Donnan exclusion of $\mathrm{OH}^{-}$ions from a CEM, the internal solution of this membrane has a $\mathrm{pH}$ value 1-2 units lower than in the external solution. As a result of this $\mathrm{pH}$ shift, the effects of facilitated diffusion $[27,28]$ and facilitated electromigration $[21,29]$ occur inside IEMs. The essence of these effects lies in the fact that getting into the acidic (or alkaline) medium inside the IEM, an amino acid zwitterion acquires a charge opposite to the charge of the membrane's fixed sites. After such a transformation, it easily passes through the IEM as a counterion. In our recent work [30], a similar mechanism was described, which explains a relatively high transport of ammonium ions (coions) through an AEM. In this case, the positively charged ammonium ion enters the alkaline AEM medium and transforms into a molecular form, which is not affected by the Donnan exclusion.

Thus, the transport of ampholytes in systems with ion-exchange membranes is coupled with chemical reactions of protonation-deprotonation. The influence of these reactions on the behavior of membrane systems in conditions of applied electric current has been described in theoretical works [31,32]. The dependence of concentration profiles of ampholyte species as well as their transport numbers in the membrane and adjacent diffusion layers on the applied current density was calculated. However, experimental verification of the model predications was not carried out.

As for the transport of phosphoric acid anions through AEM, this subject is of considerable interest not only for theory but also for practice. Isolation, purification, and concentration of these anions from municipal wastewater [33-35], animal waste [2,36], and sludge generated after its biological 
treatment [37,38] not only reduces the anthropogenic impact on the environment, but also allows for obtaining cheap fertilizers with simultaneous production of electricity [38]. It is important that the current efficiency in the recovery of phosphorus from solutions containing $\mathrm{H}_{2} \mathrm{PO}_{4}{ }^{-}$ions is significantly lower as compared to similar processes in the case of nitrates, chlorides, and other ions that do not undergo protonation-deprotonation reactions [2,34,39-41]. With an increasing potential drop, the phosphorus recovery efficiency from the desalination compartment first grows rapidly, but then remains unchanged over a wide range of voltages [23]; the recovery efficiency largely depends on the $\mathrm{pH}$ of the treated solution [39]. Some researchers explain the low efficiency of phosphorus recovery by steric hindrances that arise when transporting large, highly hydrated phosphoric acid anions [2,34].

Paltrinieri et al. [42], using the material balance equations, came to the conclusion that electric current can be transported through AEMs by doubly charged $\mathrm{HPO}_{4}{ }^{2-}$ anions, while the feed solution contains only an $\mathrm{NaH}_{2} \mathrm{PO}_{4}$ solution, where only the singly charged $\mathrm{H}_{2} \mathrm{PO}_{4}{ }^{-}$anions are present. Note that, as a rule, when choosing a current mode, researchers are guided by the limiting current, $i_{\text {lim }}$, which is found from the intersection of the tangents to the initial part and the inclined plateau of current-voltage characteristic (CVC) curves $[34,40]$. Another way to find $i_{\text {lim }}$ is through the use of the Cowan-Brown method [43] for CVC processing [44].

In this work, we report the experimental CVC and partial current densities of all orthophosphoric acid anions, namely, the $\mathrm{H}_{2} \mathrm{PO}_{4}{ }^{-}, \mathrm{HPO}_{4}{ }^{2-}$, and $\mathrm{PO}_{4}{ }^{3-}$ ions, through Neosepta AMX and Fujifilm AEM Type $X$ membranes in the case of a $0.02 \mathrm{M} \mathrm{NaH}_{2} \mathrm{PO}_{4}$ feed solution. As well, we found the fluxes of phosphorus-bearing species through the membranes under study and the partial currents of $\mathrm{H}_{2} \mathrm{PO}_{4}^{-}$and $\mathrm{H}^{+}$ions in the depleted diffusion layer adjacent to the membrane. We compared all these characteristics with the results of a simulation made using the model developed earlier [31,32]. We showed that the phosphorus-bearing species through an AEM in the ED process was less than one would expect if judging by the conventional treatment of CVC. Accordingly, we focused on the determination of limiting current density using the tangent intersection method and the Cowan-Brown method.

\section{Results and Discussion}

\subsection{Total and Partial Current-Voltage Characteristics}

Figures 1 and 2 show the experimental and calculated total and partial current-voltage characteristics (CVCs) of an AMX membrane in $\mathrm{NaCl}$ (Figure 1) and $\mathrm{NaH}_{2} \mathrm{PO}_{4}$ (Figure 2) solutions. The calculations are made using a mathematical model developed earlier $[31,32]$ and briefly described below.

In the case of $\mathrm{NaCl}$ (Figure 1), the shapes of the total and partial CVCs were close to those described in the literature $[45,46]$ for strong electrolytes, which do not participate in the proton-exchange reactions. The experimental limiting current, which is determined by the tangent intersection method (Figure 1), was close to $i_{\lim }^{L e v}$. Note that the shape of the CVCs in the range from 1.5 to $2.5 \mathrm{~mA} \cdot \mathrm{cm}^{-2}$ was rather particular. There was a region where the value of $\Delta \varphi^{\prime}$ decreased when the current density increased. The differential resistance of the membrane system within this current range was negative: $R_{d i f}=d(\Delta \varphi) / d i<0$. This "anomaly" is known for the AMX and some other IEMs [47], it is due to the early electroconvective vortex formation at electrically and geometrically heterogeneous surfaces. With growing current density in the indicated range of currents, the increasing electroconvection (occurring as electroosmosis of the first kind [48]) makes the depleted solution resistance lower. Approaching the limiting current density was manifested by a fast increase in the differential resistance with increasing $i$. Thus, to take into account the singularity $R_{\text {dif }}<0$ when determining the limiting current density, we drew the tangents to close to the linear segments of the CVCs, just before and after the occurrence of the limiting state, as shown in Figure 1.

The partial current density of $\mathrm{OH}^{-}$ions became noticeable at a reduced potential drop corresponding to the limiting current, then it slowly increased with increasing potential drop in the range corresponding to the CVC plateau (section II) and it sharply increased when $\Delta \varphi^{\prime}$ exceeded $0.8 \mathrm{~V}$, i.e., in the over-limiting regime (section III). 


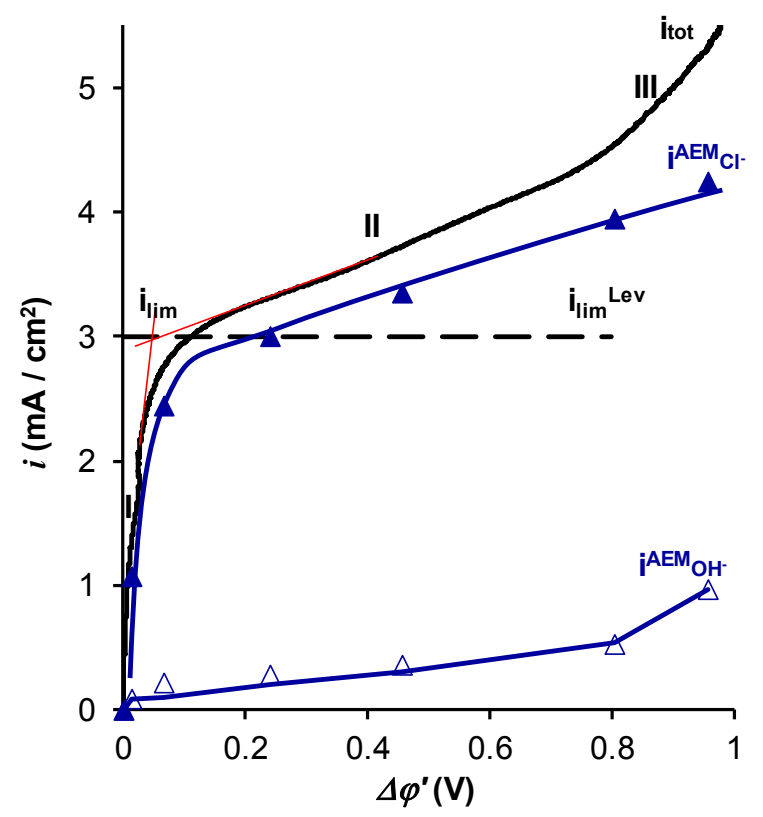

Figure 1. Total and partial current-voltage characteristics of the AMX membrane in a $0.02 \mathrm{M} \mathrm{NaCl}$ solution; $i_{\text {tot }}$ is the total current density, $i_{\mathrm{Cl}^{-}}^{\mathrm{AEM}}$ and $i_{\mathrm{OH}}^{\mathrm{AEM}}$ are the current densities of the $\mathrm{Cl}^{-}$and $\mathrm{OH}^{-}$ ions through the membrane, respectively. The dashed lines show the tangents to the CVC used to determine the experimental limiting current density.

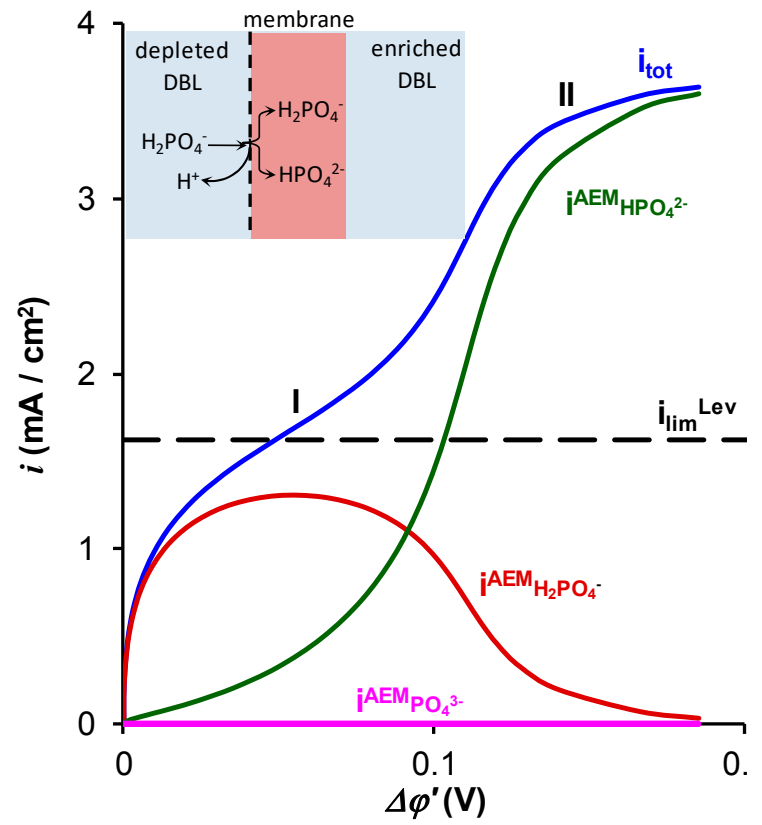

(a)

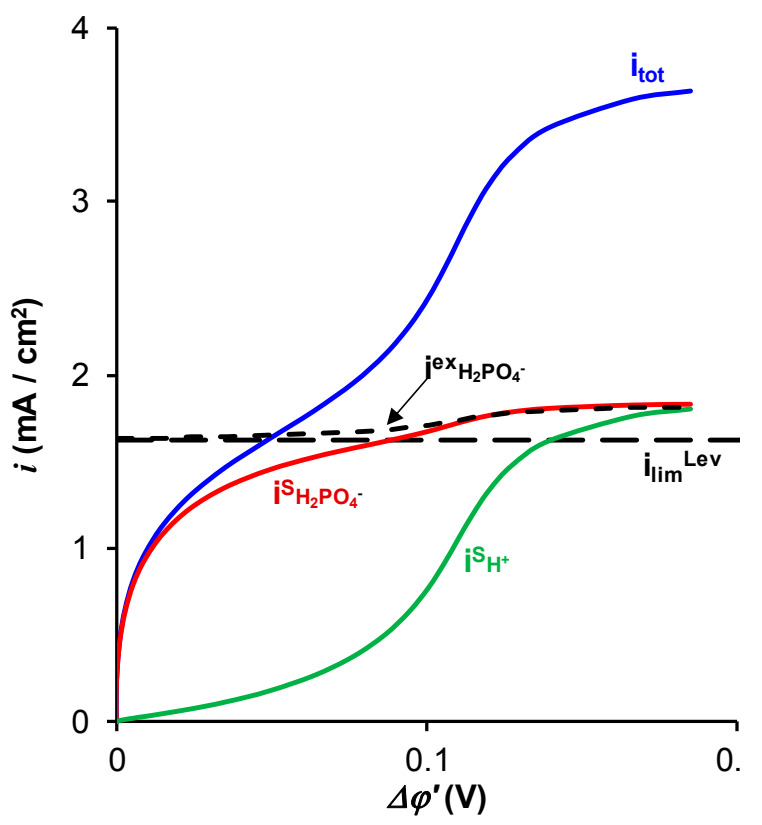

(b)

Figure 2. Theoretical total current density ( $\left.\mathrm{i}_{\text {tot }}\right)$ and partial currents of $\mathrm{H}_{2} \mathrm{PO}_{4}^{-}\left(i_{\mathrm{H}_{2} \mathrm{PO}_{4}^{-}}^{A E M}\right)$ and $\mathrm{HPO}_{4}{ }^{2-}$ $\left(i_{\mathrm{HPO}_{4}{ }^{2-}}^{\mathrm{AEM}}\right)$ ions in an AMX membrane (a) as well as the partial currents of $\mathrm{H}_{2} \mathrm{PO}_{4}^{-}\left(i_{\mathrm{H}_{2} \mathrm{PO}_{4}^{-}}^{\mathrm{s}}\right)$ and $\mathrm{H}^{+}$ $\left(i_{H^{+}}^{s}\right)$ ions in the depleted solution at the membrane surface $(\mathbf{b})$ as functions of the corrected potential drop. Solid lines were calculated using the model [31,32]. Dashed lines show the limiting current $i \lim$ calculated using the Leveque equation, Equation (6), and the exaltation current, $i_{\mathrm{H}_{2} \mathrm{PO}_{4}{ }^{-}}$, calculated using Equation (1). "I" and "II" show the first and second inclined plateaus, respectively.

The shape of $i_{O H^{-}}^{A E M}$ versus $\Delta \varphi^{\prime}$ dependence shown in Figure 1 is fully consistent with well-established ideas about the development of water splitting with the catalytic participation of fixed-membrane groups: the generation of $\mathrm{H}^{+}$and $\mathrm{OH}^{-}$ions at the membrane/solution interface 
begins when the concentration of $\mathrm{NaCl}$ in the boundary solution at the membrane surface reaches values of about $5 \times 10^{-5} \mathrm{M}$ [49], and the $\mathrm{H}^{+}\left(\mathrm{OH}^{-}\right)$ions in the depleted solution start to compete with the $\mathrm{Na}^{+}$and $\mathrm{Cl}^{-}$ions. This state occurs when the current density is close to the limiting current density at a potential drop across the depleted diffusion layer of about $0.25 \mathrm{~V}$ [49]. The rate of water splitting increases with an increase in the potential drop [50]. The partial current of $\mathrm{Cl}^{-}$ions, $i_{\mathrm{Cl}}^{-}$, continues to grow after reaching the value $i_{\lim }^{\mathrm{Lev}}$ due to the effect of exaltation of the limiting current $[51,52]$ and the development of electroconvection $[49,53]$.

In the case of the $\mathrm{NaH}_{2} \mathrm{PO}_{4}$ solution, the model developed in References [31,32] predicts the presence of two inclined plateaus on the total CVC (Figure 2). In the region of the first plateau (about $0.05 \mathrm{~V}$ of the reduced potential drop), the partial current density of singly charged ions $\mathrm{H}_{2} \mathrm{PO}_{4}{ }^{-}$in the membrane reached a maximum value that was close to the limiting current calculated by the Leveque equation. The limiting current calculated by the Leveque equation is the limiting value of the partial current carried by $\mathrm{H}_{2} \mathrm{PO}_{4}{ }^{-}$ions in solution, where this current is limited by diffusion through the depleted diffusion layer. When $\Delta \varphi^{\prime}$ is close to $0.05 \mathrm{~V}$, the concentration of $\mathrm{H}_{2} \mathrm{PO}_{4}{ }^{-}$ions at the AEM surface reach a value which is much lower than the concentration value in the bulk solution, hence, its diffusion flux density attains a maximum [31,32].

Thus, the appearance of the first plateau was due to the saturation of the $\mathrm{NaH}_{2} \mathrm{PO}_{4}$ salt diffusion from the solution to the membrane surface (Figure $2 b$ ).

The decrease in $\mathrm{NaH}_{2} \mathrm{PO}_{4}$ concentration in the solution at the AEM surface led to a stronger Donnan exclusion of protons from the membrane. As a result, the $\mathrm{pH}$ of the AEM internal solution increased and a higher part of the singly charged phosphate $\mathrm{H}_{2} \mathrm{PO}_{4}{ }^{-}$ions transformed into doubly charged $\mathrm{HPO}_{4}{ }^{2-}$ ions when crossing the membrane interface: $\mathrm{H}_{2} \mathrm{PO}_{4}{ }^{-} \rightarrow \mathrm{HPO}_{4}{ }^{2-}+\mathrm{H}^{+}$(insert in Figure 2a). The protons released into the solution at the depleted membrane interface were involved in the charge transfer in the depleted DBL forming partial current density $i^{\mathrm{s}} \mathrm{H}_{+}$(Figure 2b). When the fluxes of $\mathrm{PO}_{4}{ }^{3-}$ and $\mathrm{OH}^{-}$ions in the membrane were negligible, $i_{\mathrm{H}^{+}}^{s}=i_{\mathrm{HPO}_{4}{ }^{2-}}^{A E M}$ (Figure 2a). These protons appearing in solution and the doubly charged $\mathrm{HPO}_{4}{ }^{2-}$ anions in the membrane caused the rise of current density above the first limiting current density, $i_{\mathrm{lim}}^{1}$. The second plateau (and limiting current, $i_{\text {lim }}^{2}$ ) was observed when the membrane was completely converted into the $\mathrm{HPO}_{4}{ }^{2-}$ form. In this state, the flux of protons, released when the $\mathrm{H}_{2} \mathrm{PO}_{4}{ }^{-}$anions entered the membrane and transformed into $\mathrm{HPO}_{4}{ }^{2-}$, was saturated.

Experimental values of the partial current densities through the AMX and Fuji membranes were calculated using the value of the $\mathrm{HPO}_{4}{ }^{2-}$ ion flux density, $j_{\mathrm{H}_{2} \mathrm{PO}_{4}{ }^{-}}^{\mathrm{s}}$, which was measured using the method described in Section 3.2.1. Namely, $j_{\mathrm{H}_{2} \mathrm{PO}_{4}{ }^{-}}$was found from the rate of the $\mathrm{NaH}_{2} \mathrm{PO}_{4}$ removal from the diluate in the batch mode ED, Equation (14). Then, using Equations (15)-(20), it was possible to calculate the partial current densities of the $\mathrm{H}_{2} \mathrm{PO}_{4}{ }^{-}, \mathrm{HPO}_{4}{ }^{2-}, \mathrm{PO}_{4}{ }^{3-}$ and $\mathrm{OH}^{-}$ions in a membrane, by applying these equations in pairs in a proper range of $\mathrm{pH}$. For example, when the $\mathrm{pH}$ of the membrane internal solution was between 5 and 10, Equations (15) and (18) allow calculation of $i_{\mathrm{H}_{2} \mathrm{PO}_{4}{ }^{-}}^{A A M}$ and $i_{\mathrm{HPO}_{4}{ }^{2-}}^{A E M}$. If the calculated value of $i_{\mathrm{H}_{2} \mathrm{PO}_{4}{ }^{-}}^{A A M}$ is less than zero, it insinuates that the $\mathrm{pH}$ in the membrane is higher than 10, and the $\mathrm{PO}_{4}{ }^{3-}$ anions are involved in current transfer instead of $\mathrm{H}_{2} \mathrm{PO}_{4}{ }^{-}$. Then, Equations (19) and (20) must be used. As Figure 3 shows, the contribution of the $\mathrm{PO}_{4}{ }^{3-}$ ions into the charge transfer in the membranes becomes significant only at relatively high current densities (exceeding approximately $3 i_{l i m}{ }^{\text {Lev }}$ ). Thus, we did not reach the conditions where the $\mathrm{OH}^{-}$ions pass across the membrane because of the limitations of the measuring device. 


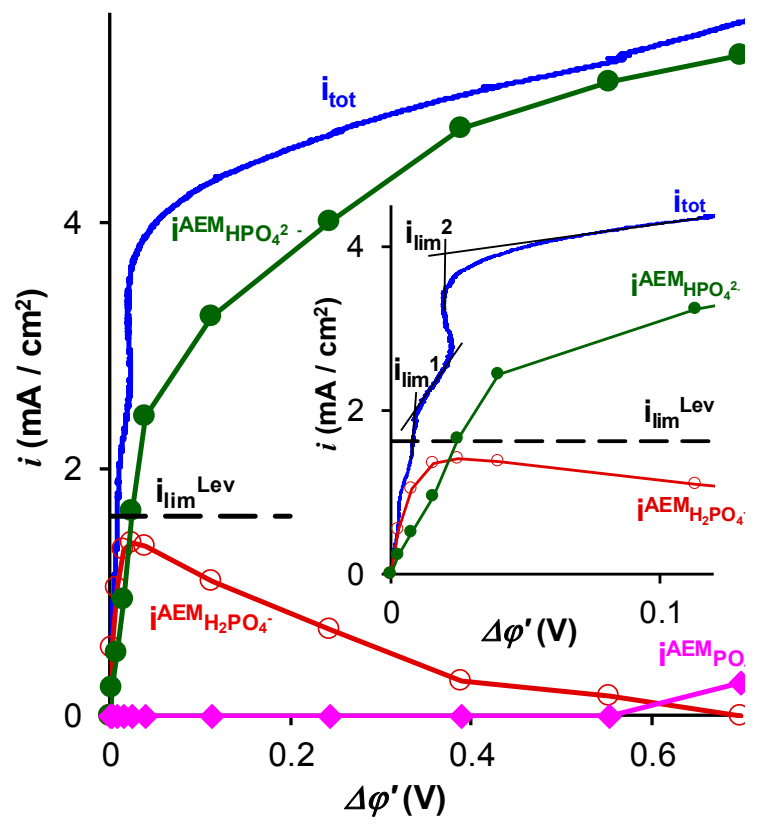

(a)

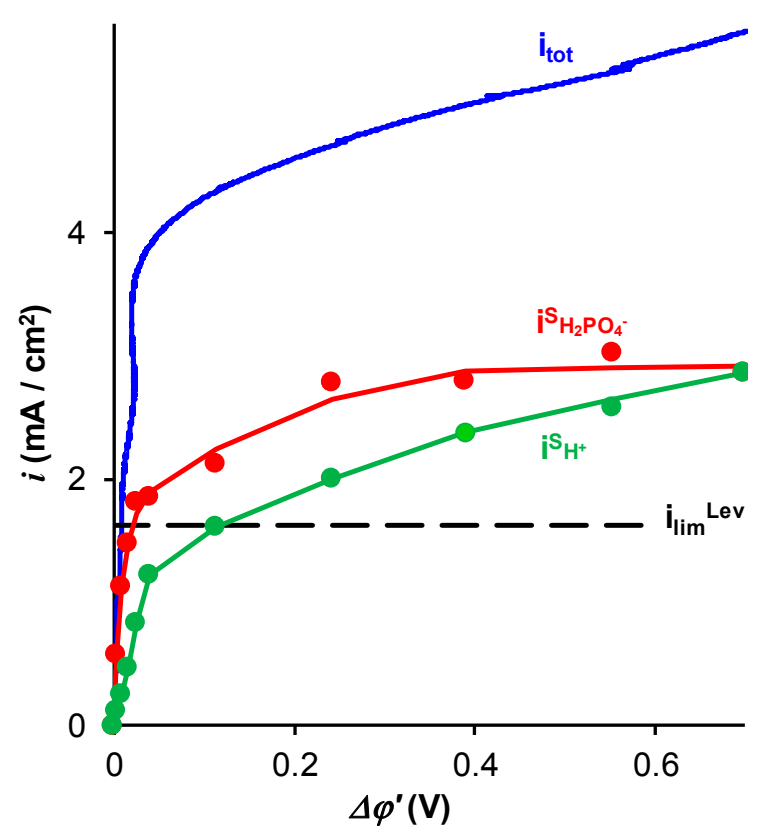

(c)

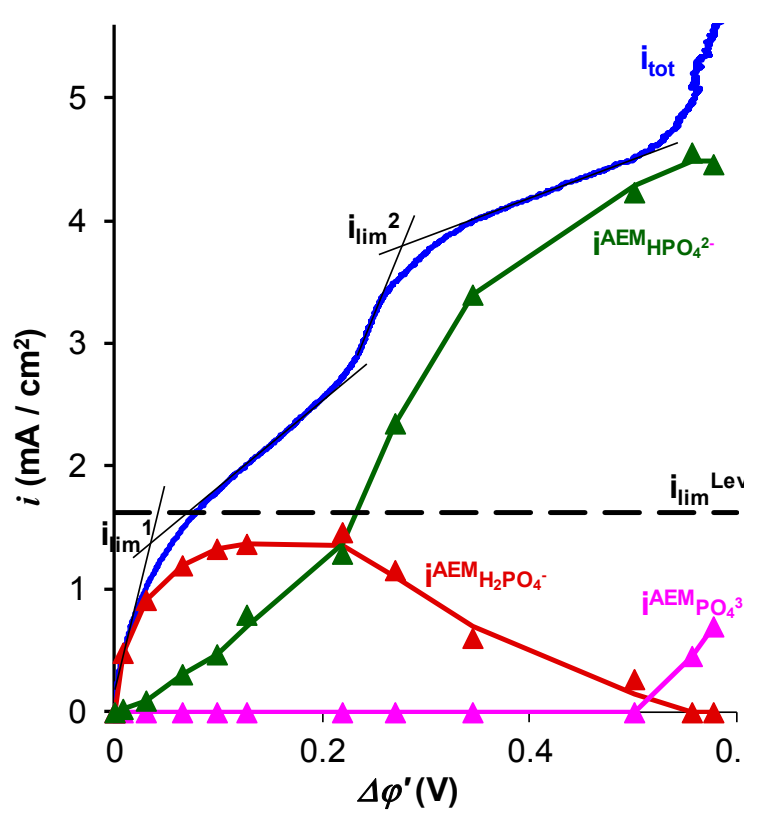

(b)

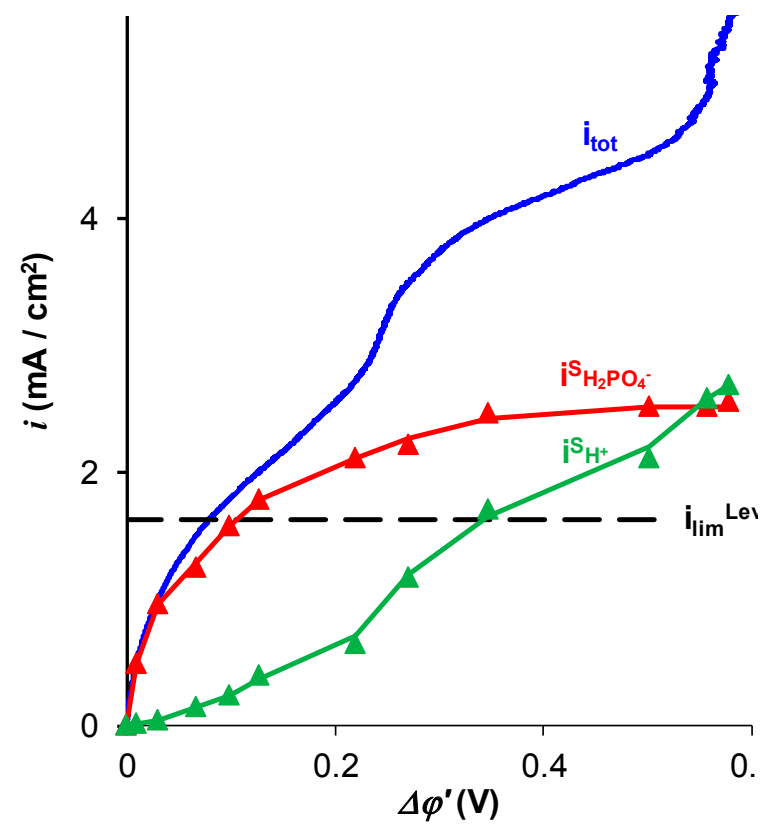

(d)

Figure 3. Experimental total current density $\left(i_{\text {tot }}\right)$ and partial currents of $\mathrm{H}_{2} \mathrm{PO}_{4}^{-}\left(i_{\mathrm{H}_{2} \mathrm{PO}_{4}^{-}}^{A E M}\right), \mathrm{HPO}_{4}{ }^{2-}$ $\left(i_{\mathrm{HPO}_{4}{ }^{2-}}^{A E M}\right)$, and $\mathrm{PO}_{4}{ }^{3-}\left(i_{\mathrm{PO}_{4}{ }^{3-}}^{\mathrm{AEM}}\right)$ ions in AMX (a) and AEM Fuji Type X (b) membranes, as well as partial currents of $\mathrm{H}_{2} \mathrm{PO}_{4}^{-}{ }^{-}\left(i_{\mathrm{H}_{2} \mathrm{PO}_{4}{ }^{-}}\right)$and $\mathrm{H}^{+}\left(i_{\mathrm{H}^{+}}^{\mathrm{S}}\right)$ in depleted solution near AMX (c) and AEM Fuji Type X (d) membranes as functions of the corrected potential drop. The curves connecting the markers are the fitting lines. The data were obtained in a $0.02 \mathrm{M} \mathrm{NaH}_{2} \mathrm{PO}_{4}$ solution. The dashed lines show the limiting current $i_{\lim }^{\mathrm{Lev}}$ calculated using Equation (6).

When $\mathrm{HPO}_{4}{ }^{2-}$ and $\mathrm{PO}_{4}{ }^{3-}$ ions cross the membrane boundary with the enriched solution and appear in aqueous solution, they capture $\mathrm{H}^{+}$ions from water, which leads to an increase in $\mathrm{pH}$ of the enriched solution. It can be also interpreted as the generation of $\mathrm{OH}^{-}$ions at the membrane/enriched solution interface. Thus, in membrane systems with $\mathrm{NaH}_{2} \mathrm{PO}_{4}$ solution, the process of generation 
of $\mathrm{H}^{+}$and $\mathrm{OH}^{-}$ions is separated in space: the $\mathrm{H}^{+}$ions appear at the depleted solution/membrane interface and the $\mathrm{OH}^{-}$ions at the membrane/enriched solution interface. The contribution of the $\mathrm{OH}^{-}$ transport in the charge transfer in the membrane becomes essential only at sufficiently high current densities/potential drops, when the $\mathrm{pH}$ of the internal membrane solution is greater than 13 (see Section 3.2.1.). Therefore, when $\mathrm{pH}<13$, the transport of $\mathrm{OH}^{-}$ions across the membrane is negligible. In the experiments in this study, the situation where the transport of $\mathrm{OH}^{-}$ions was measurable was not achieved because of the limitations of the measuring device.

\subsubsection{Contributions of Electroconvection and Exaltation Effects.}

The comparison of the results of the experiment (Figures 3 and $4 a$ ) and simulation using the model [31,32] (Figures 2 and 4a) for the values of $i_{\text {tot }}$ and $i_{i}$ as functions of $\Delta \varphi^{\prime}$ showed that they were in relatively good agreement. The difference lies in the fact that for a given reduced potential drop (up to $\Delta \varphi^{\prime}=0.2 \mathrm{~V}$, which is the maximum value for which the computations according to the model are possible), the experimental values of $i_{\text {tot }}$ and $i_{\mathrm{H}_{2} \mathrm{PO}_{4}{ }^{-}}^{\mathrm{AEM}}$ were slightly higher than that predicted by the model. The experimental phosphorus flux density, $j_{P}=i_{\mathrm{H}_{2} \mathrm{PO}_{4^{-}}}^{s} / F$, through the membranes under study (Figure 4), determined by Equation (13), also exceeded the values calculated using this model [32].

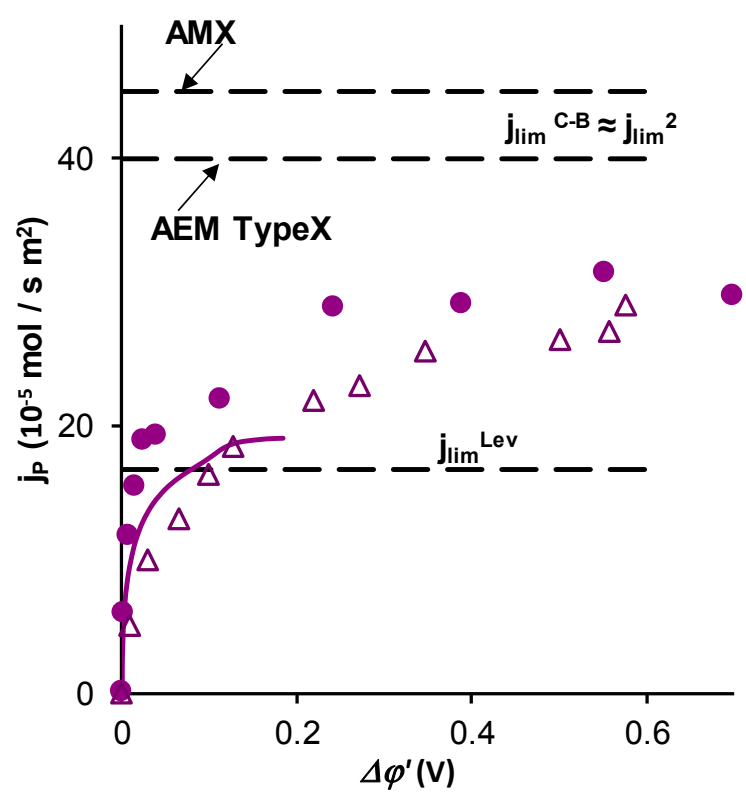

Figure 4. Experimental (markers) and calculated using the model [31,32] (solid line) total phosphorus flux density through the AMX (circles) and AEM Type-X (triangles) membrane vs. the reduced potential drop. Here $j_{\lim }{ }^{\text {Lev }}=i_{\text {lim }}{ }^{\text {Lev } / F} F$, where $i_{\text {lim }}{ }^{\text {Lev }}$ is calculated using Equation $(6) ; j_{\lim }{ }^{\mathrm{C}-\mathrm{B}}=i_{\mathrm{lim}}{ }^{\mathrm{C}-\mathrm{B} /} F$, where $i_{\text {lim }}{ }^{\text {C-B }}$ is found from the CVC curves by the Cowan-Brown method [43].

The increase in the flux density of $\mathrm{H}_{2} \mathrm{PO}_{4}{ }^{-}$ions from the bulk solution to the AEM surface $\left(j_{\mathrm{H}_{2} \mathrm{PO}_{4}{ }^{-}}\right)$ over the value corresponding to the limiting current density $i_{\text {lim }}{ }^{\text {Lev }}$ can be caused only by two effects: (1) electroconvection, which reduces the effective thickness of the diffusion layer and (2) exaltation of the $\mathrm{H}_{2} \mathrm{PO}_{4}{ }^{-}$current. As shown in References [49,54], the contribution of gravitational convection in such systems is negligible. Figure $2 \mathrm{~b}$ shows the calculated partial current density of $\mathrm{H}_{2} \mathrm{PO}_{4}{ }^{-}$ions, $\left(i_{\mathrm{H}_{2} \mathrm{PO}_{4}-}\right)_{\text {electrodif }}$, which would occur if the ion transport was only due to electro-diffusion, taking into 
account the effect of exaltation [51], while the electroconvection was not taken into account. The calculation is carried out using the following equation [32]:

$$
\left(i_{\mathrm{H}_{2} \mathrm{PO}_{4}}^{\mathrm{s}}\right)_{\text {electrodif }}=i_{\lim }^{\mathrm{Lev}}+i^{e x}=i_{\lim }^{\mathrm{Lev}}+\frac{D_{\mathrm{H}_{2} \mathrm{PO}_{4}^{-}}}{D_{\mathrm{H}^{+}}} i_{\mathrm{H}^{+}}
$$

where $i_{\lim }^{\mathrm{Lev}}$ is the limiting value of the $\mathrm{H}_{2} \mathrm{PO}_{4}{ }^{-}$ion current density (calculated by Equation (6)) achieved by electro-diffusion in the absence of exaltation, and the second term, $i^{e x}$, describes the increase in the current density owing to the exaltation effect. This effect is due to the protons released from the $\mathrm{H}_{2} \mathrm{PO}_{4}{ }^{-}$ions when they enter the membrane. The $\mathrm{H}^{+}$ions carry a positive charge, which creates an additional electrostatic field attracting the $\mathrm{H}_{2} \mathrm{PO}_{4}{ }^{-}$anions from the bulk solution to the depleted membrane surface [51].

However, as can be seen from Figure $2 b$, the exaltation effect is too weak to provide the experimentally observed $\mathrm{H}_{2} \mathrm{PO}_{4}{ }^{-}$ions' flux in the diffusion layer near the membrane surface (equal to the total flux of phosphorus atoms through the membrane). Consequently, the main cause of growth should be electroconvection, which, as it known from References [48,49,53,55], significantly increases the mass transfer in dilute solutions of strong electrolytes. Our experiments show that in the systems under study, in the case of $\mathrm{NaCl}$ solution, the first large vortex structures (about $50 \mu \mathrm{m}$ in size) are visualized at the outlet of the channel under study, when $i / l_{\mathrm{lim}}{ }^{\mathrm{Lev}}=2$. With an increasing current, the vortex structures gradually spread along the entire length of the channel, and the dimensions of the vortices increase. At $i / i_{\text {lim }}{ }^{\text {Lev }}=6$ (Figure $5 \mathrm{a}$ ), the vortex structures occupy almost half of the $900 \mu \mathrm{m}$ intermembrane space.

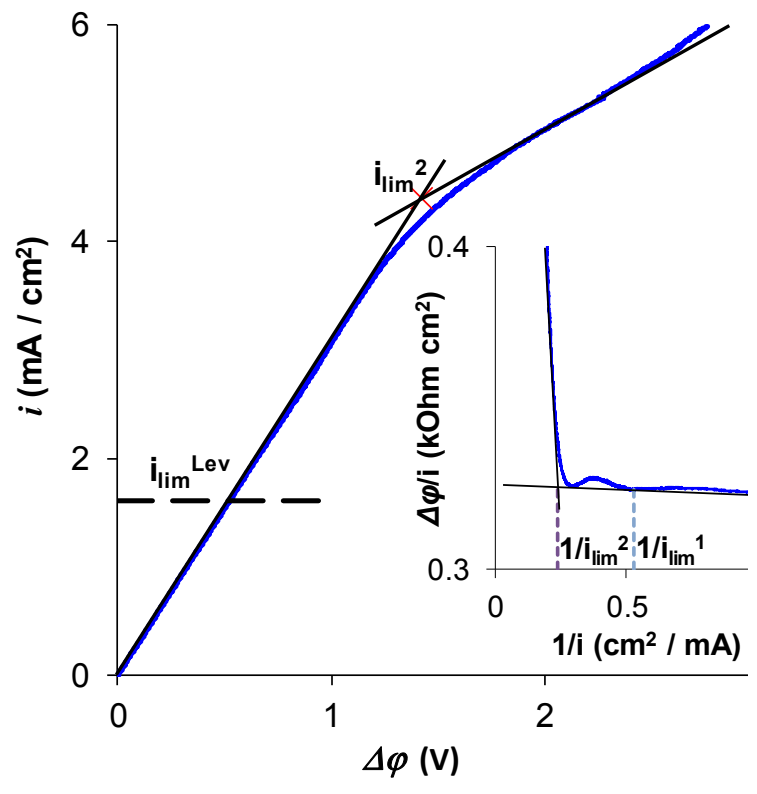

(a)

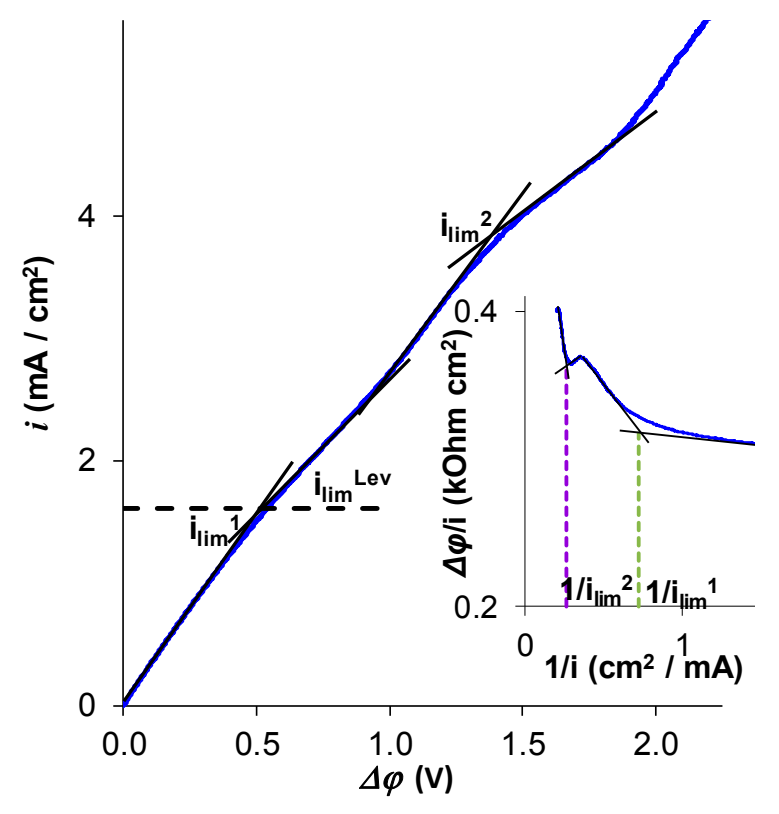

(b)

Figure 5. Current-voltage characteristics presented in the usual coordinates and the coordinates proposed by Cowan and Brown [43] (the insertion) for an AMX (a) and AEM Type X (b) membranes. $i_{\lim }{ }^{1}$ and $i_{\text {lim }}{ }^{2}$ were the first and the second limiting currents determined by the tangent intersection method. The dashed lines in the insertions show the positions of the $1 / i_{\mathrm{lim}}{ }^{1}$ and $1 / i_{\mathrm{lim}}{ }^{2}$ points on the Cowan-Brown curves. The experiments were carried out in a $0.02 \mathrm{M} \mathrm{NaH}_{2} \mathrm{PO}_{4}$ solution.

The scenario of the electroconvective structures' development in the $\mathrm{NaH}_{2} \mathrm{PO}_{4}$ solution was the same as in the case of the $\mathrm{NaCl}$ solution. The difference was that the vortices of the same diameter 
emerged at essentially higher current densities, e.g., those with a diameter of $50 \mu \mathrm{m}$ only formed when $i / i_{\lim }{ }^{\text {Lev }}=6$ (Figure $6 \mathrm{~b}$ ).

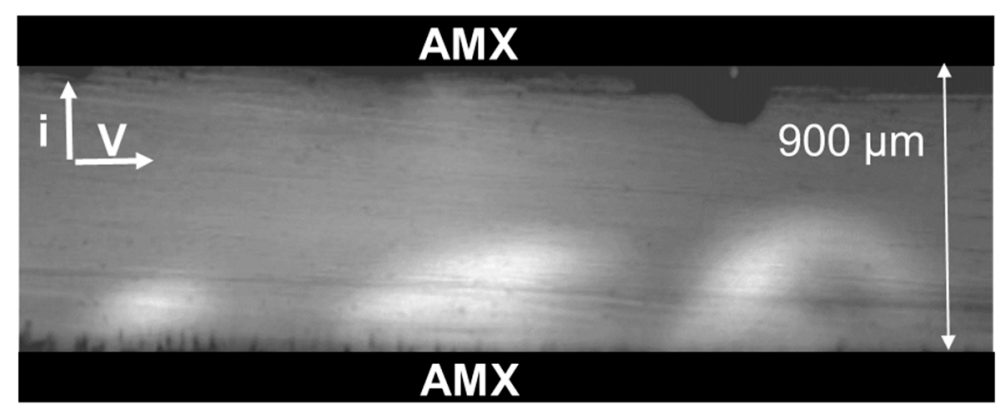

(a)

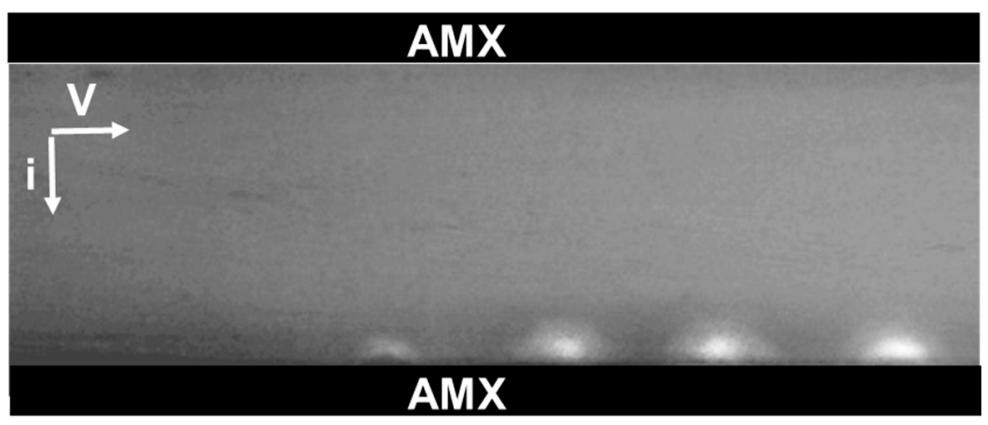

(b)

Figure 6. Visualization of the vortex structures at the AMX membrane surface in the desalination channel of the electrodialysis cell, where a $0.01 \mathrm{M} \mathrm{NaCl}$ solution (a) or a $0.01 \mathrm{M} \mathrm{NaH}_{2} \mathrm{PO}_{4}$ (b) was pumped. The intermembrane distance was $h=0.9 \mathrm{~mm}$, the channel length was $L=3 \mathrm{~mm}$, the linear flow velocity of the solution was $V=1 \mathrm{~mm} / \mathrm{s} ; / / \mathrm{lim}^{\mathrm{Lev}}=6$.

The reason for the weaker electroconvection in the case of the $\mathrm{NaH}_{2} \mathrm{PO}_{4}$ solution, apparently, was the high rate of $\mathrm{H}^{+}$ion generation at the same value of the $i / i_{\text {lim }}$ ratio. Getting into the space charge region at the depleted membrane surface, the $\mathrm{H}^{+}$ions caused a decrease in its density [56]. In the case of strong electrolyte solutions, the generation of $\mathrm{H}^{+}$(and $\mathrm{OH}^{-}$) ions occurred, as noted above, after reaching a certain threshold concentration of salt ions near the membrane surface. After overcoming this threshold (which requires a certain minimum potential drop), the $\mathrm{H}^{+}$and $\mathrm{OH}^{-}$ions were generated as a result of "water splitting" occurring as proton-exchange reactions with catalytic participation of fixed groups at the membrane/solution interface [57-60]. In the case of the $\mathrm{NaH}_{2} \mathrm{PO}_{4}$ solution, the generation of $\mathrm{H}^{+}$ions occurred in the non-threshold mode as a result of the dissociation of a part of $\mathrm{H}_{2} \mathrm{PO}_{4}{ }^{-}$ions when they enter the membrane bulk. This process takes place as soon as an external electric field was applied to the membrane.

\subsubsection{Rate of Phosphorus Removal from Feed Solution and Its Theoretical Assessment.}

The rate of phosphorus removal from the feed solution is controlled by the flux density of the $\mathrm{H}_{2} \mathrm{PO}_{4}{ }^{-}$ions from the feed bulk solution to the anion-exchange membrane surface. Since the $\mathrm{pH}$ of the feed solution was close to 4.5 , there were no other phosphorus-bearing species except for the $\mathrm{H}_{2} \mathrm{PO}_{4}{ }^{-}$ions. As mentioned above, the electro-diffusion flux of the $\mathrm{H}_{2} \mathrm{PO}_{4}{ }^{-}$ions was limited by the first limiting current density, $i_{\text {lim }}{ }^{1}$ (which was very close to the theoretical value $i_{\text {lim }}{ }^{\text {Lev }}$ ); exaltation and electroconvection can enhance this transport.

It should be noted that the charge transfer by doubly and triply charged anions of orthophosphoric acid through the membrane, as well as the transport of $\mathrm{OH}^{-}$ions, are parasitic processes if the purpose 
of electrodialysis is the removal of phosphorus from the feed solution. Therefore, the phosphorus flux density, $j_{\mathrm{P}}$, which is transported through the AEM by all the phosphorus-bearing particles, Equation (13), turns out to be significantly less than what one would expect if the formula $j=i_{\text {lim }} / F$ (where $j$ is the effective transport; $i_{\text {lim }}$ is the limiting current density through the membrane) is used by the analogy with strong electrolytes. In the practice of electrodialysis, the value of $i_{\lim }$ was found using CVC and applying the tangent intersection method [12], or the Cowan-Brown method [43], as explained above. In the last case, the integral resistance of the membrane system (equal to $\Delta \varphi / i$ ) was presented as a function of the inverse current density, $1 / i$ (Figure 4).

As can be seen in Figure 5, the experimental determination of $i_{\mathrm{lim}}{ }^{1}$ was difficult if the CVC with the total potential drop, $\Delta \varphi$, was used, both when the tangent intersection method or the Cowan-Brown method were applied. However, the second plateau and the second limiting current density, $i_{\mathrm{lim}}{ }^{2}$, which corresponds to the state where the membrane is completely transformed into the form of doubly charged $\mathrm{HPO}_{4}{ }^{2-}$ ions, were essentially better pronounced on the CVC. When the Cowan-Brown coordinates (Figure 5a,b, insertions) were used, the region of the curve related to $i_{\lim }{ }^{1}$ was very close to a straight line. The limiting current density $i{ }_{\lim }^{C-B}$, usually found as the intersection point to two nearly linear regions of the $\Delta \varphi / i$ versus $1 / i$ curve, was then rather close to the second limiting current, $i_{\text {lim }}{ }^{2}$, since the singularity of the curve related to $i_{\text {lim }}{ }^{1}$ in these coordinates was quasi invisible, especially if a more rough scale (as usual) was used. Thus, when the CVC is recorded with insufficient accuracy, confusion may occur: the second limiting current density can be taken as the current density, which determines the rate of phosphorus removal.

The first limiting current is difficult to see, apparently, because the approach to saturation in the $\mathrm{H}_{2} \mathrm{PO}_{4}^{-}$ion diffusion transport in solution is accompanied by a rapid increase in the contribution to charge transfer of $\mathrm{H}^{+}$ions, released when $\mathrm{H}_{2} \mathrm{PO}_{4}^{-}$enters the membrane. As shown by mathematical modeling [32], the plateau of the first limiting current was the less noticeable the smaller the difference in values of the dissociation constants related to the first $\left(\mathrm{K}_{\mathrm{a} 1}\right)$ and the second $\left(\mathrm{K}_{\mathrm{a} 2}\right)$ steps of the ampholyte dissociation. In the case of phosphoric acid, the difference between $\mathrm{pK}_{\mathrm{a} 1}=2.12$ and $\mathrm{pK}_{\mathrm{a} 2}=7.21$ was nevertheless rather large. This difference was essentially lower for a number of other weak acids, such as tartaric acid $\left(\mathrm{pK}_{\mathrm{a} 1}=2.98\right.$ and $\left.\mathrm{pK}_{\mathrm{a} 2}=4.34[61,62]\right)$. Thus, one can expect that the detection of the first limiting current would be even more difficult than in the case of phosphoric acid.

The practical question of how to detect the first limiting current density is quite important. Let us note that the plateau related to $i_{\text {lim }}{ }^{1}$ was easily detectable when using the $i$ versus $\Delta \varphi^{\prime}$ coordinates (Figure 3a,b). The use of the $i$ versus $\Delta \varphi$ coordinates (Figure 5a,b) makes the detection of $i_{\lim }{ }^{1}$ essentially more uncertain; the second limiting current may be taken for the first one. Nevertheless, if the maximum rate of phosphorus removal, $j_{\mathrm{P}} \max$, is evaluated by $i_{\mathrm{lim}}{ }^{2}$, the obtained value will be approximately 1.5 times higher than the experimentally measured value of $j_{\mathrm{P}}{ }^{\max }$ in this study. Apparently, it is particularly the overestimation of the limiting current, which is responsible for the unexpectedly high energy consumption and low current efficiency of the ED recovery of phosphorus and other ampholyte species, reported by several authors $[10,34,39,41]$.

\section{Materials and Methods}

\subsection{Membrane and Solutions}

The Neosepta AMX anion-exchange membrane was manufactured (Astom, Japan) using a previously described method [63-65]. This membrane contained quaternary ammonium bases and a small amount of secondary and tertiary amines [66]. It had an undulated surface: there were "hills" and "valleys" located in staggered order. This order was caused by the geometry of PVC reinforcing fabric [67]. The average difference between the highest and the lowest points on the surface of the swollen membrane was about $30 \mu \mathrm{m}$ [67]. The characteristic size of the geometric inhomogeneity along the surface $(280 \mu \mathrm{m})$ was close in magnitude to the thickness of the diffusion layer adjacent to the membrane in the compartments of the electrodialysis cell used in the study. The AMX membrane 
thickness in a $0.02 \mathrm{M} \mathrm{NaCl}$ solution and the ion exchange capacity of swollen membrane were equal to $125 \pm 5 \mu \mathrm{m}$ and $1.23 \pm 0.05 \mathrm{mmol} \cdot \mathrm{g}^{-1}$ wet, respectively.

The basis of the homogeneous AEM Type X membrane (Fujifilm, The Netherlands) was a three-dimensional structure (substrate) of inert polyolefin fibers [68], which were obtained by electroforming [69] methods. The aerogel formed by the fibers was pressed to a predetermined thickness. The space among the fibers was then filled with aliphatic polyacrylamide $[70,71]$ and functionalized with quaternary ammonium bases [72]. The AEM Type $X$ thickness in a $0.02 \mathrm{M} \mathrm{NaCl}$ solution and the ion exchange capacity of swollen membrane were equal to $120 \pm 5 \mu \mathrm{m}$ and $1.50 \pm 0.05 \mathrm{mmol} \cdot \mathrm{g}^{-1}$ wet, respectively.

All membrane samples underwent a standard salt pretreatment [73] and then were equilibrated with a $0.02 \mathrm{M}$ salt solution before experiments. The solutions of sodium chloride $(\mathrm{NaCl})$ and monosodium phosphate $\left(\mathrm{NaH}_{2} \mathrm{PO}_{4}\right)$ were prepared from a crystalline salt (analytical grade) provided by OJSC Vekton; the $0.10 \mathrm{M} \mathrm{NaOH}$ solution was prepared from a titrant (manufactured by Uralkhiminvest, Russia). $\mathrm{NaOH}$ was used to maintain a constant $\mathrm{pH}$ value of the solution circulating through the compartments of the measuring cell. Distilled water, with an electrical conductivity of $0.8 \mu \mathrm{S} \cdot \mathrm{cm}^{-1}$, $\mathrm{pH}=6.0 \pm 0.2$, and temperature of $25^{\circ} \mathrm{C}$, was used to prepare the solutions. Table 1 shows several characteristics of the electrolyte solutions used in the experiments.

Table 1. Several characteristics of the electrolyte solutions and membrane systems under study. The data are related to the temperature, $25^{\circ} \mathrm{C}$.

\begin{tabular}{|c|c|c|c|c|c|c|c|}
\hline \multirow[t]{2}{*}{ Electrolyte, $\mathrm{pH}$} & \multicolumn{3}{|c|}{$\begin{array}{l}\text { Diffusion Coefficients at Infinite } \\
\text { Dilution, } D_{i}, 10^{-5} \mathrm{~cm}^{2} \mathrm{~s}^{-1}\end{array}$} & \multicolumn{2}{|c|}{$\begin{array}{l}\text { Transport Numbers at } \\
\text { Infinite Dilution }\end{array}$} & \multirow{2}{*}{$\begin{array}{l}\text { Theoretical Limiting } \\
\text { Current Density in } 0.02 \mathrm{M} \\
\text { Solution }{ }^{*}, \mathrm{~mA} \mathrm{~cm}^{-2}\end{array}$} & \multirow{2}{*}{$\begin{array}{c}\text { Diffusion Laye } \\
\text { Thickness }{ }^{*} \\
\mu \mathrm{m}\end{array}$} \\
\hline & Cation & Anion & Electrolyte & Cation & Anion & & \\
\hline $\mathrm{NaCl} p H=5.70 \pm 0.05$ & 1.334 & $2.032[61]$ & $1.61[75]$ & 0.396 & 0.604 & 3.07 & 256 \\
\hline $\mathrm{NaH}_{2} \mathrm{PO}_{4} \mathrm{pH}=4.60 \pm 0.05$ & {$[61,74]$} & $0.959[61]$ & $1.11[74]$ & 0.581 & 0.419 & 1.62 & 225 \\
\hline
\end{tabular}

Figure 7 shows the distribution of the phosphoric acid species (in mole fractions) as a function of $\mathrm{pH}$. It is calculated using the equations for the equilibrium of protonation-deprotonation reactions on the first, second, and third steps:

$$
\begin{gathered}
\mathrm{H}_{3} \mathrm{PO}_{4}+\mathrm{H}_{2} \mathrm{O} \Leftrightarrow \mathrm{H}_{2} \mathrm{PO}_{4}^{-}+\mathrm{H}_{3} \mathrm{O}^{+} \\
\mathrm{H}_{2} \mathrm{PO}_{4}^{-}+\mathrm{H}_{2} \mathrm{O} \Leftrightarrow \mathrm{HPO}_{4}^{2-}+\mathrm{H}_{3} \mathrm{O}^{+} \\
\mathrm{HPO}_{4}^{2-}+\mathrm{H}_{2} \mathrm{O} \Leftrightarrow \mathrm{PO}_{4}^{3-}+\mathrm{H}_{3} \mathrm{O}^{+}
\end{gathered}
$$

Negative logarithms of the equilibrium constants of these reactions at $25^{\circ} \mathrm{C}$ are equal to [61] 2.12 $\left(\mathrm{pK}_{\mathrm{a} 1}\right), 7.21\left(\mathrm{pK}_{\mathrm{a} 2}\right)$, and $12.34\left(\mathrm{pK}_{\mathrm{a} 3}\right)$.

\subsection{Methods}

The measurements of the electrochemical characteristics of AEMs were carried out at a temperature of $25 \pm 1{ }^{\circ} \mathrm{C}$ using a flow-through four-compartment electrodialysis laboratory cell connected to an Autolab PGSTAT-100 electrochemical complex. The setup and the cell are described in detail in Reference [30,49]. A schematic design of the setup is shown in Figure 8. The intermembrane distance in the desalination compartment (14), $h$, was equal to $6.6 \mathrm{~mm}$; the linear flow velocity of the electrolyte solution through each chamber, $V$, was $0.4 \mathrm{~cm} \cdot \mathrm{s}^{-1}$; the polarizable area of the membrane was $2 \times 2 \mathrm{~cm}^{2}$; the tips of Luggin's capillaries (5) used to record the potential drop across the membrane under study were located at a distance of approximately $0.8 \mathrm{~mm}$ from its surfaces. The plexiglass frames separating the membranes in the electrodialysis cell (Figure 7) were equipped with special guides in the shape of a comb, which provided laminar regime of the solution flow in the cell compartments. 


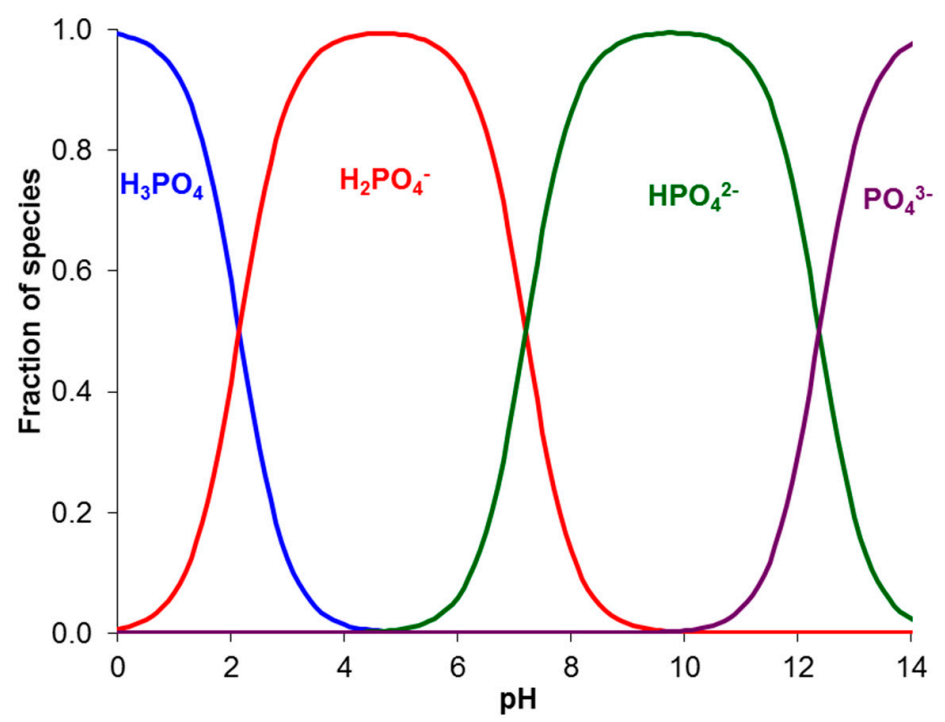

Figure 7. Distribution of the phosphoric acid species (in mole fractions) in a solution as a function of $\mathrm{pH}$.

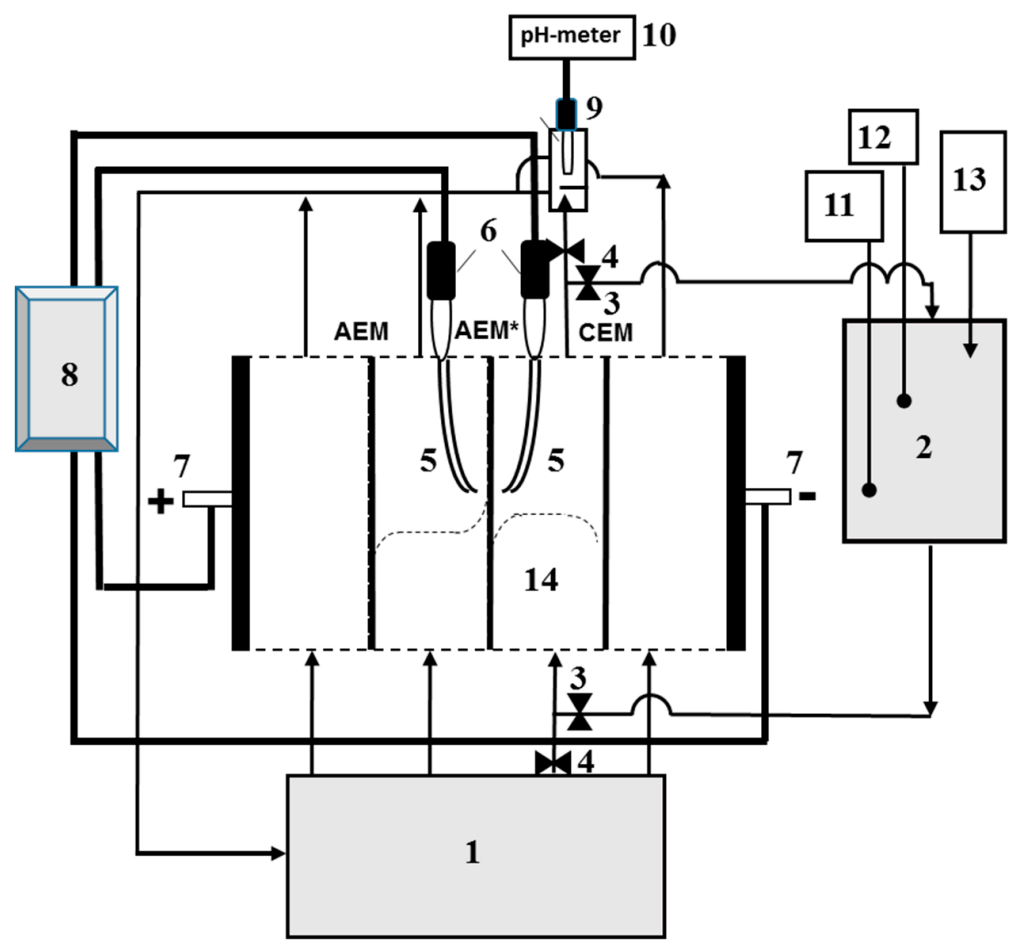

Figure 8. Schematic design of the setup used for determining the mass transfer and electrochemical characteristics of the cation-exchange membrane (CEM) and anion-exchange membrane (AEM) forming the desalination compartment (14). The setup included: an intermediate feed tank (1); an additional tank (2) for maintaining a constant $\mathrm{pH}$; valves (3, 4); Luggin capillaries (5) connected with measuring $\mathrm{Ag} / \mathrm{AgCl}$ electrodes (6); platinum polarizing electrodes (7); an electrochemical complex (an Autolab PGSTAT-100) (8); a flow cell (9) with an immersed combined electrode for $\mathrm{pH}$ measurement; a $\mathrm{pH}$ meter (10) connected to a computer; a combined electrode for $\mathrm{pH}$ measurement (11) connected to a $\mathrm{pH}$ meter; a conductivity cell (12) connected to a conductometer; a device (13) for maintaining a constant $\mathrm{pH}$ in the solution circulating through tank (2); $\mathrm{AEM}^{*}$ is the anion-exchange membranes under study; CEM and AEM are the auxiliary membranes. The dotted lines schematically show the counterion concentration profiles in the cell compartments. 
The current-voltage characteristics (CVC) were measured in the galvanodynamic mode at a current sweep rate of $0.02 \mu \mathrm{A} \cdot \mathrm{s}^{-1}$. Measuring $\mathrm{Ag} / \mathrm{AgCl}$ electrodes EVL-1M3.1 (Gomel, Belorussia) with a working area of several tenths of $\mathrm{cm}^{2}$ immersed in saturated $\mathrm{KCl}$ solution were used. The volume of the feed solution in tank (1) at the beginning of the experiment was $5 \mathrm{dm}^{3}$. This solution was fed to all of the compartments of the cell and then returned to the same tank. Due to the relatively large volume of this solution and the fact that the diluate and concentrate were mixed before returning to tank (1), the deviation of the species' concentrations in the tank from their initial values during one run of the experiment did not exceed $1 \%$.

The total potential drop, $\Delta \varphi$, measured using Luggin capillaries (5) depends, along with the potential drop across the polarized diffusion layers, on the resistance of the membrane and solution. The latter is a function of the distance between the membrane and capillaries (5) [76]. This distance is difficult to find and reproduce when replacing one membrane with another one. To exclude this difficulty, the corrected potential drop $\Delta \varphi^{\prime}[77]$ is used instead of $\Delta \varphi$ :

$$
\Delta \phi^{\prime}=\Delta \phi-i R_{e f}
$$

where the effective resistance of the membrane system $R_{e f}\left(\mathrm{Ohm} \mathrm{cm}^{2}\right)$ includes the ohmic resistance of the space (membrane + solution) among the measuring capillaries, as well as the diffusion resistance of the interphase boundaries of depleted and enriched diffusion layers [49]. The value of $R_{e f}$ is found from the initial part of the CVC by extrapolation $i \rightarrow 0$ in the coordinates $i$ versus $d(\Delta \varphi) d i$.

The limiting current density, $i_{\text {lim }}^{\mathrm{Lev}}$, was calculated using the Leveque equation obtained in the framework of the convective-diffusion model [78]. A 1:1 electrolyte can be expressed as:

$$
i_{\lim }^{L e v}=1.47\left[\frac{F D C}{h\left(T_{i}-t_{i}\right)}\left(\frac{h^{2} V}{L D}\right)^{1 / 3}-0.2\right]
$$

where $L$ is the desalination channel length; $C\left(\right.$ mole $\left.\cdot \mathrm{dm}^{-3}\right)$ is the electrolyte concentration of the feed solution at the entrance to the desalination channel; $D$ is the electrolyte diffusion coefficient at infinite dilution (Table 1 ); $t_{i}$ is the transport number of salt counter-ion in solution at infinite dilution (Table 1); $T_{i}$ is the effective transport number of salt counter-ion in the membrane. The latter is defined as the fraction of the electric current transferred by ions " $i$ " without restrictions on the concentration or pressure gradients; for the investigated membranes in the given solutions, the values of $T_{i}$ for the salt coions $\left(\mathrm{Na}^{+}\right)$are taken to be zero.

According to the definition above:

$$
T_{i}=\frac{z_{i} j_{i} F}{i}=\frac{i_{i}}{i}
$$

where $z_{i}$ and $j_{i}$ are the ion charge number and the flux density, $F$ is the Faraday constant; $i_{i}=z_{i} j_{i} F$ is the partial current density of ion $i$.

Since $j_{i}$ in general cases change with the coordinate normal to the membrane surface, $T_{\mathrm{i}}$ is a function of this coordinate. In particular, if the solution $\mathrm{pH}$ is close to 4.5 , the main phosphorus-bearing species is $\mathrm{H}_{2} \mathrm{PO}_{4}^{-}$. In the membrane, $\mathrm{pH}$ is $1-3$ units higher $[16,24,26]$, therefore, together with $\mathrm{H}_{2} \mathrm{PO}_{4}^{-}$, the presence of doubly charged $\mathrm{HPO}_{4}{ }^{2-}$, and even triply charged $\mathrm{PO}_{4}{ }^{3-}$, is possible.

The average of the cell length thickness of the diffusion layer, $\delta$, is estimated by combining the Leveque and the Peers equations [32]

$$
\delta=0.68 h\left(\frac{L D}{h^{2} V}\right)^{1 / 3}
$$

The values of $i_{\text {lim }}{ }^{L e v}$ and $\delta$ for each electrolyte are summarized in Table 1. 


\subsubsection{Effective Transport Numbers, $T_{i}$}

The values of the effective transport numbers, $T_{i}$, and partial currents of counter-ions are obtained using the same cell as when measuring the total CVC. For measuring $T_{i}$, desalination compartment (14) was fed with a solution from the additional tank (2). Before an experiment was run, the circuit consisting of the desalination channel, tank (2), and connecting tubes were filled with a $0.035 \mathrm{M}$ solution of the electrolyte under study $\left(\mathrm{NaCl}\right.$ or $\left.\mathrm{NaH}_{2} \mathrm{PO}_{4}\right)$. The other circuits of the cell were fed with a $0.02 \mathrm{M}$ solution of $\mathrm{NaCl}$ or $\mathrm{NaH}_{2} \mathrm{PO}_{4}$ from tank (1). The initial electrolyte concentration in tank (2) was $0.035 \mathrm{M}$; it decreased during one experimental run to $0.01 \mathrm{M}$. In this concentration range, the coion $\left(\mathrm{Na}^{+}\right)$transferred through the anion-exchange membrane can be neglected [79]. As well, in this concentration range, the concentration of carbonic acid dissociation products formed due to the continuous dissolution of atmospheric carbon dioxide in the working solution is negligible [80].

The initial volume of the solution in the desalination circuit (including tank (2), the desalination compartment and connecting tubes) was $0.100 \pm 0.002 \mathrm{dm}^{3}$; the solution flows among the membranes at a velocity of $0.40 \pm 0.01 \mathrm{~cm} \cdot \mathrm{s}^{-1}$. The volume, concentration, and flow velocity of the solution were selected in a way to ensure quasi-stationary conditions for desalination during an experimental run. In separate experiments, it was found that to meet these conditions, the rate of electrical conductivity decreased in the desalting circuit (in the solution circulating through tank (2)) should not exceed 1\% per minute [80].

The experiment was carried out at a constant corrected potential drop $\Delta \varphi^{\prime}$. At equal time intervals $(10 \mathrm{~min})$, the electrical conductivity $(\kappa), \mathrm{pH}$, and temperature of the solution in tank (2) (Figure 8) were recorded using a combined electrode for $\mathrm{pH}$ measurement (11) connected to the $\mathrm{pH}$ meter Expert 001 and the submersible conductometric cell (12) connected to the conductometer Expert 002 (LLC "Ekoniks expert", Russia). In all cases presented in this paper, the solution leaving the desalination compartment of the cell (compartment (14) in Figure 8) was acidified. To maintain a constant $\mathrm{pH}$ of the desalination stream close to $5.7 \pm 0.05(\mathrm{NaCl})$ or to $4.6 \pm 0.05\left(\mathrm{NaH}_{2} \mathrm{PO}_{4}\right)$, a $0.1 \mathrm{M} \mathrm{NaOH}$ solution was continuously added into tank (2) using a micro capillary (13). The electrolyte concentration in tank (2) was periodically determined by measuring the solution conductivity in this tank and using an equation, which connects the concentration of $\mathrm{NaCl}$ or $\mathrm{NaH}_{2} \mathrm{PO}_{4}$ solution with its conductivity.

The concentration of the solution in the desalination circuit changes with time due to the transfer of electrolyte ions through the membranes forming the desalination compartment to the neighboring compartments, as well as due to the addition of a titrant into this tank. The mass balance for a salt ion 1 (e.g., a cation) in the desalination circuit is described by Equation (9), under the assumption that the difference in concentrations in the different elements of this circuit (tank (2), the cell and connecting tubes) is negligible [30]:

$$
\bar{V} \frac{d C}{d t}=-\frac{i\left(T_{1}^{C E M}-T_{1}^{A E M}\right) S n}{z_{1} F}+C_{T} \frac{d \overline{V_{T}}}{d t}
$$

where $i$ is the current density; $T_{1}^{C E M}$ and $T_{1}^{A E M}$ are the effective transport numbers of ion 1 in the cation-exchange membrane and anion-exchange membrane, respectively, which form the desalination compartment; $\mathrm{C}$ is the current salt concentration $\left(\mathrm{NaCl}\right.$ or $\left.\mathrm{NaH}_{2} \mathrm{PO}_{4}\right)$ in tank (2); $\bar{V}$ is the volume of the solution in the desalination circuit; $n$ is the number of desalination compartments $(n=1) ; C_{T}$ and $\bar{V}_{T}$ are the concentration and volume of the titrant, which is added to tank (2) to compensate for changes in $\mathrm{pH}$ caused by the $\mathrm{H}^{+}\left(\mathrm{OH}^{-}\right)$generation at the membrane/solution interfaces; $S$ is the area of active (polarizable) membrane surface. As it was mentioned above, the solution after passing the desalination compartment (14) was acidified, hence, a $\mathrm{NaOH}$ solution was added to the desalination stream.

The first term on the right-hand side of Equation (9) describes the decrease in the salt concentration in the tank (2) caused by the flow of electric current across the AEM and CEM; the second term describes the addition of a titrant in tank (2). 
Consider the case of $\mathrm{NaCl}$ solution and a CEM under study. If the transfer of cations $\left(\mathrm{Na}^{+}\right)$ through the auxiliary AEM is neglected $\left(T_{1}^{A E M}=0\right)$, it follows from Equation (9) that:

$$
j_{N a^{+}}^{C E M}=\frac{i_{N a^{+}}^{C E M}}{F}=\frac{i T_{N a^{+}}^{C E M}}{F} \approx-\frac{\bar{V}}{S} \frac{d C}{d t}+\frac{C_{T}}{S} \frac{d \overline{V_{T}}}{d t}
$$

In the case where an AEM is under study, Equation (9) should be written for the $\mathrm{Cl}^{-}$ions. Like as above, we assumed that the auxiliary membrane (CEM) was not permeable for anions, i.e., $T_{\mathrm{Cl}^{-}}^{\mathrm{CEM}}=0$. Since the $\mathrm{Cl}^{-}$ions were not present in the titrant added to tank (2), Equation (9) reads:

$$
j_{C l^{-}}^{A E M}=\frac{i_{C l^{-}}^{A E M}}{F}=\frac{i T_{C l^{-}}^{A E M}}{F} \approx-\frac{\bar{V}}{S} \frac{d C}{d t}
$$

When the transport numbers of the salt cation in the CEM $\left(\mathrm{Na}^{+}\right)$and the salt anion $\left(\mathrm{Cl}^{-}\right)$in the AEM were determined, the transport numbers of the $\mathrm{H}^{+}$ion in the $\mathrm{CEM}$ and $\mathrm{OH}^{-}$ion in the AEM were found according to Equation (12):

$$
T_{H^{+}}^{C E M}=1-T_{N a^{+}}^{C E M}, T_{\mathrm{OH}^{-}}^{A E M}=1-\mathrm{T}_{\mathrm{Cl}^{-}}^{A E M}
$$

In the case of the $\mathrm{NaH}_{2} \mathrm{PO}_{4}$ solution desalination, the calculation of the partial currents of sodium ions and protons in CEM was carried out according to Equations (10) and (12).

The determination of the partial currents of $\mathrm{H}_{2} \mathrm{PO}_{4}{ }^{-}, \mathrm{HPO}_{4}{ }^{2-}, \mathrm{PO}_{4}{ }^{3-}$, and $\mathrm{OH}^{-}$ions through an AEM was carried out using the material balance equations presented below. The following assumptions were made for their deduction.

1. The total phosphorus flux through an AEM, $j_{P}^{A E M}$, is equal to the sum of fluxes of all phosphorus-bearing ions entering the AEM from the diluate compartment. Since only the $\mathrm{H}_{2} \mathrm{PO}_{4}{ }^{-}$ ions were present at $\mathrm{pH}=4.6$ in this compartment, we have, $j_{\mathrm{H}_{2} \mathrm{PO}_{4}^{-}}^{\mathrm{s}}$ :

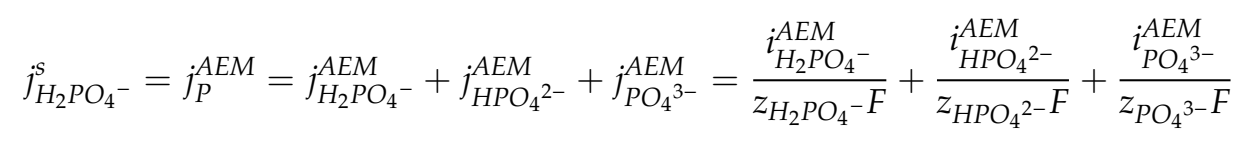

where superscripts " $s$ " and " $A E M$ " relate to the solution at the diluate side of the membrane and the AEM, respectively.

The $j_{\mathrm{H}_{2} \mathrm{PO}_{4}{ }^{-}}^{\mathrm{s}}$ value can be determined experimentally by the rate of $\mathrm{NaH}_{2} \mathrm{PO}_{4}$ concentration decrease in the desalination stream (where the $\mathrm{pH}$ was kept constant), in accordance with an equation which is similar to Equation (11):

$$
j_{\mathrm{H}_{2} \mathrm{PO}_{4}}^{\mathrm{s}}=-\frac{\bar{V}}{\mathrm{~S}} \frac{d \mathrm{C}_{\mathrm{NaH}_{2} \mathrm{PO}_{4}}}{d t}
$$

2. From the distribution of the phosphoric acid species as a function of $\mathrm{pH}$ (Figure 8), it follows that only two sorts of phosphorous-containing species can be present in an AEM: either $\mathrm{HPO}_{4}{ }^{2-}$ and $\mathrm{HPO}_{4}{ }^{2-}$ (when the $\mathrm{pH}$ of the internal solution is in the range from 5 to 10 ) or $\mathrm{HPO}_{4}{ }^{2-}$ and $\mathrm{PO}_{4}{ }^{3-}$ (pH from 10 to 13). The concentrations of the remaining species in any of the three $\mathrm{pH}$ ranges presented above are so small that they can be neglected. The third possible pair, $\mathrm{PO}_{4}{ }^{3-}$ and $\mathrm{OH}^{-}$can coexist at $\mathrm{pH}>13$. At $\mathrm{pH}=13$, the molar fraction of $\mathrm{PO}_{4}{ }^{3-}$ in the membrane is close to 0.8 and that of $\mathrm{HPO}_{4}{ }^{2-}$, 0.2 , while the concentration of $\mathrm{OH}^{-}$ions is $0.1 \mathrm{M}$, which is about $5 \%$ of the exchange capacity, hence, the total concentration of phosphate species. However, taking into account the high mobility of $\mathrm{OH}^{-}$ ions, it can be assumed that these ions will compete with the $\mathrm{PO}_{4}{ }^{3-}$ ions, whose content is dominant at this $\mathrm{pH}$ value.

Since the $\mathrm{H}^{+}$ions being coions are excluded from the anion-exchange membrane, the $\mathrm{pH}$ of the membrane internal solution is 1 to $2 \mathrm{pH}$ units higher than the $\mathrm{pH}$ of the external solution [16]. The coion exclusion increases with the dilatation of the external solution contacting the membrane, as it 
follows from the well-known Donnan equation [81]. With an increasing current density, the solution contacting the membrane surface at its diluate side becomes increasing diluted and the concentration of the $\mathrm{H}^{+}$ions in the near-surface membrane layer decreases, so that the $\mathrm{pH}$ of the internal solution in this layer increases. Therefore, the composition of the membrane near-surface layer on the diluate side varies with the current density: at relatively low current density (low concentration polarization), the $\mathrm{pH}$ in the membrane internal solution is relatively low, and this layer contains mainly ions $\mathrm{H}_{2} \mathrm{PO}_{4}^{-}$ and $\mathrm{HPO}_{4}{ }^{2-}$. With increasing current density, the concentration polarization increases, the external boundary solution becomes more diluted, the $\mathrm{pH}$ in the membrane internal solution becomes higher, and the membrane near-surface layer is enriched firstly with the $\mathrm{PO}_{4}{ }^{3-}$ ions, and then, with the $\mathrm{OH}^{-}$ions.

In the $\mathrm{pH}$ range from 5 to 10 (relatively low current densities), where only $\mathrm{H}_{2} \mathrm{PO}_{4}{ }^{-}$and $\mathrm{HPO}_{4}{ }^{2-}$ are present in the membrane, the total current density, $i$, is carried exclusively by these ions:

$$
i_{\mathrm{H}_{2} \mathrm{PO}_{4}^{-}}^{\mathrm{AEM}}+i_{\mathrm{HPO}_{4}{ }^{2-}}^{\mathrm{AEM}}=i
$$

and, according to Equation (13):

$$
j_{\mathrm{H}_{2} \mathrm{PO}_{4}^{-}}^{s}=\frac{i_{\mathrm{H}_{2} \mathrm{PO}_{4}{ }^{-}}^{A E M}}{F}+\frac{i_{\mathrm{HPO}_{4}{ }^{2-}}^{A E M}}{2 F}
$$

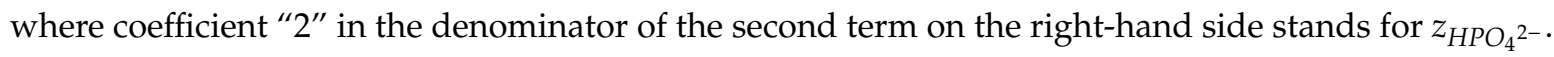
Then, the partial current densities of singly and doubly charged phosphorus-bearing anions can be found from the two following equations:

$$
\begin{aligned}
& i_{\mathrm{H}_{2} \mathrm{PO}_{4}{ }^{-}}^{\mathrm{AEM}}=2 \mathrm{Fj}_{\mathrm{H}_{2} \mathrm{PO}_{4}{ }^{-}}^{\mathrm{S}}-i \\
& i_{\mathrm{HPO}_{4}{ }^{2-}}^{\mathrm{AEM}}=2\left(i-F j_{\mathrm{H}_{2} \mathrm{PO}_{4}^{-}}^{\mathrm{s}}\right)
\end{aligned}
$$

Thus, we can calculate the partial current densities of the $\mathrm{H}_{2} \mathrm{PO}_{4}{ }^{-}$and $\mathrm{HPO}_{4}{ }^{2-}$ species, if we measure the current density, $i$, and the rate of the diluate desalination; the latter allows for the calculation of $j_{\mathrm{H}_{2} \mathrm{PO}_{4}^{-}}^{\mathrm{s}}$ Equation (14).

In the range of $\mathrm{pH}$ from 10 to 13.5 (high current densities), where $i_{\mathrm{HPO}_{4}{ }^{2-}}^{A E M}+i_{\mathrm{PO}_{4}{ }^{3-}}^{A A M}=i$, in a similar way, we find:

$$
\begin{aligned}
& i_{\mathrm{HPO}_{4} 4^{2-}}^{\mathrm{AOM}}=2\left(3 \mathrm{Fj}_{\mathrm{H}_{2} \mathrm{PO}_{4}{ }^{-}}^{\mathrm{s}}-i\right) \\
& i_{\mathrm{PO}_{4}{ }^{3-}}^{\mathrm{AOM}}=3\left(i-2 \mathrm{Fj}_{\mathrm{H}_{2} \mathrm{PO}_{4}}^{\mathrm{s}}\right)
\end{aligned}
$$

The coefficients 2 and 3 in Equations (17)-(20) stands for the charge numbers $z_{\mathrm{HPO}_{4}{ }^{2-}}$ and $z_{\mathrm{PO}_{4}{ }^{3-}}$, respectively.

At even higher current densities, where all doubly charged orthophosphoric acid anions transform into triple-charged ones $\left(T_{\mathrm{HPO}_{4}^{2-}}=i_{\mathrm{HPO}_{4}^{2-}} / i=0\right)$ and the $\mathrm{pH}$ of the internal solution exceeds 13.5 , the current is transported through the membrane by $\mathrm{PO}_{4}{ }^{3-}$ and $\mathrm{OH}^{-}$ions. The partial currents of these ions are:

$$
\begin{gathered}
i_{\mathrm{PO}_{4}{ }^{3-}}^{A E M}=3 F_{\mathrm{H}_{2} \mathrm{PO}_{4}{ }^{-}}^{\mathrm{S}} \\
i_{\mathrm{OH}^{-}}^{A E M}=i-i_{\mathrm{PO}_{4}{ }^{3-}}^{A E M}
\end{gathered}
$$

In accordance with Equations (2)-(4) and (13), at the AEM/solution interface, the partial flux of protons entering the depleted diffusion layer is:

$$
j_{H^{+}}^{s}=j_{H P O_{4}^{2-}}^{A E M}+2 j_{P O^{-}}^{A E M}
$$


Taking into account that $i_{k}=j_{k} z_{k} F$, the partial current density of $\mathrm{H}^{+}$ions in the depleted solution near the membrane surface is:

$$
i_{H^{+}}^{\mathrm{s}}=\frac{i_{\mathrm{HPO}_{4}^{2-}}^{\mathrm{AEM}}}{2}+\frac{2 i_{\mathrm{PO}_{4}{ }^{3-}}^{\mathrm{AEM}}}{3}
$$

\subsubsection{Visualization of Electroconvective Vortices.}

Visualization of vortex flows near an AMX membrane surface facing the desalination compartment was carried out using a technique similar to that described in Reference [82].

Two poly(methyl methacrylate) frames clung close to the ion-exchange membrane and formed a channel, with a $0.9 \mathrm{~mm}$ width and a $3 \mathrm{~mm}$ length. A $0.01 \mathrm{M} \mathrm{NaCl}$ or $0.01 \mathrm{M} \mathrm{NaH}_{2} \mathrm{PO}_{4}$ solution entered the desalination compartment through the holes in the clamping plates, in which the electrode chambers were located. The linear flow rate of the solution was $0.001 \mathrm{~cm} \cdot \mathrm{s}^{-1}$. The distance from the investigated membranes to the measuring electrodes was $800 \mu \mathrm{m}$. To visualize vortexes, $10 \mu \mathrm{M}$ rhodamine $6 \mathrm{G}$ was added to the solution. Rhodamine 6G is able to fluoresce in a narrow range of wavelengths and it is a large cation. The chlorine or hydrogen phosphate ions were the anions in the system under study. A SOPTOP CX40M optical microscope (China) with a $5 \times$ objective and a digital eyepiece camera were used to record these vortexes. The resolution of the digital optical system allows for the recording of the appearance of vortices with a diameter of 20 microns or greater. Digital video recording was carried out simultaneously while measuring the potential difference over the membrane, and the current density through the membrane was set as a function of time. The limiting current density was estimated from the current-voltage characteristic of the membrane using the tangent intersection method.

\section{Theory}

The calculation of the CVC, as well as the transport numbers, partial fluxes, and partial currents of ions in the membrane system was carried out using a stationary 1D model described in detail in References [31,32]. A three-layer system under direct current conditions was considered. It consisted of an anion-exchange membrane (AMX) and two adjacent diffusion boundary layers (DBLs). Migration and diffusion transport of neutral and negatively charged ampholyte species, as well as the $\mathrm{Na}^{+}$, $\mathrm{H}^{+}$, and $\mathrm{OH}^{-}$ions in all three layers, is described using the Nernst-Planck equation under the local electroneutrality condition. The model assumes the independence of the current density and the sum of the fluxes of all phosphorus-bearing species from the coordinate. As well, local chemical equilibria were assumed among the ampholyte species involved in protonation-deprotonation reactions in the AEM and DBLs. In addition, the condition of the ion-exchange equilibrium (expressed by the Donnan equations) at the membrane/solution boundaries was applied. The ion diffusion coefficients in the solution (Table 1) were taken at the infinite dilution [83], because at the near-limiting current densities, the ion concentrations in the solution next to membrane surface were close to zero. The diffusion coefficients in the membrane were determined from the AMX membrane conductivity [84].

\section{Conclusions}

The transport of the singly charged phosphoric acid anions, $\mathrm{H}_{2} \mathrm{PO}_{4}{ }^{-}$, across an AEM was accompanied by dissociation of a part of these anions when entering the membrane. The $\mathrm{H}^{+}$ions released in this dissociation returned to the depleted solution and participates in carrying electric charge. The generation of $\mathrm{H}^{+}$ions occurred without voltage threshold, which existed in the case of strong electrolytes. Depending on the current density, the $\mathrm{H}_{2} \mathrm{PO}_{4}{ }^{-}$anions could transform into $\mathrm{HPO}_{4}{ }^{2-}$ ions (at relatively low current densities, approximately at $i<2.5 i_{\text {lim }}{ }^{\mathrm{Lev}}$ ) or $\mathrm{PO}_{4}{ }^{3-}$ ions (at higher current densities). At relatively high current densities/voltages along with this transformation, water splitting with catalytic participation of membrane functional groups can occur.

The dissociation of the $\mathrm{H}_{2} \mathrm{PO}_{4}^{-}$anion occurred because the $\mathrm{pH}$ of the membrane internal solution was higher than the $\mathrm{pH}$ of the external solution. The shift in $\mathrm{pH}$ was due to the Donnan exclusion of 
the $\mathrm{H}^{+}$ions, which were coions for the AEM. The degree of the $\mathrm{H}^{+}$exclusion (hence, the $\mathrm{pH}$ of the internal solution) depends on the electrolyte concentration in the boundary solution: the more dilute this solution, the higher the internal solution's $\mathrm{pH}$. Since the concentration of the boundary solution decreased with increasing current density, the internal solution $\mathrm{pH}$ increased with increasing $i$, as a consequence, the equivalent fraction of doubly and triply charged anions in the membrane increased.

Each step of the $\mathrm{H}_{2} \mathrm{PO}_{4}{ }^{-}$anion dissociation had a response on the I-V curve. When the boundary electrolyte concentration became much lower than the bulk concentration, an inclined plateau of the first limiting electric current was observed. When $i>i_{\text {lim }}{ }^{1}$, a more complete transformation of the $\mathrm{H}_{2} \mathrm{PO}_{4}{ }^{-}$anion into the $\mathrm{HPO}_{4}{ }^{2-}$ ions in the membrane occurred, the $\mathrm{H}^{+}$ions liberated in this reaction gave rise to the electric current. The second plateau appeared when the membrane passed completely in the $\mathrm{HPO}_{4}{ }^{2-}$ form. The next rise in the current density occurred due to the appearance of the $\mathrm{PO}_{4}{ }^{3-}$ ions in the membrane and a new portion of the $\mathrm{H}^{+}$ions ejected into the depleted solution. When $\mathrm{HPO}_{4}{ }^{2-}$ and $\mathrm{PO}_{4}{ }^{3-}$ ions crossed the membrane boundary and into the enriched solution on the other side of the membrane, they captured $\mathrm{H}^{+}$ions from water, which led to an increase of $\mathrm{pH}$ in the enriched solution. It can be also interpreted as generation of $\mathrm{OH}^{-}$ions at the membrane/enriched solution interface. Thus, in $\mathrm{AEM} / \mathrm{NaH}_{2} \mathrm{PO}_{4}$ systems, the process of generation of $\mathrm{H}^{+}$and $\mathrm{OH}^{-}$ions is separated in space: $\mathrm{H}^{+}$ions appear at the depleted solution/membrane interface and $\mathrm{OH}^{-}$ions at the membrane/enriched solution interface.

Following from the above, phosphorus can be transferred across the membrane by singly, doubly or triply charged anions. However, the origin of all these species are the $\mathrm{H}_{2} \mathrm{PO}_{4}{ }^{-}$anions presented in the feed solution. Hence, the sum of the phosphorus-bearing species fluxes is equal to the flux of the $\mathrm{H}_{2} \mathrm{PO}_{4}{ }^{-}$anions from the bulk solution to the depleted membrane boundary. $\mathrm{The}_{2} \mathrm{H}_{2} \mathrm{PO}_{4}{ }^{-}$ions are transported by electro-diffusion including the exaltation effect and by electroconvection. The Leveque equation gives the limiting current density not including the exaltation effect; the latter gives an increase in the phosphorus flux approximately equal to $10 \%$, and electroconvection (in the conditions of our experiment) gives the contribution of about $60 \%$ to the overall flux. The occurrence of electroconvection was established via visualization of electroconvective vortices. It was shown that under the same value of $i / i_{\mathrm{lim}}{ }^{\mathrm{Lev}}$, the size of electroconvective vortices in the case of $0.02 \mathrm{M} \mathrm{NaH}_{2} \mathrm{PO}_{4}$ solution was essentially lower than in the case of $\mathrm{NaCl}$ solution of the same concentration. Thus, what is important is that increasing current densities/voltages in ED systems does not lead to expected growth of the extraction degree of phosphorus. Increasing current density is spent particularly in the $\mathrm{H}^{+}$ions' transport. Electroconvection is less effective, as in the case of $\mathrm{NaCl}$, since the $\mathrm{H}^{+}$ions reduce the space charge at the depleted solution/membrane interface. Hence, with increasing current density over $i_{\text {lim }}$ Lev, the current efficiency of the phosphorus recovery strongly decreases.

Another interesting remark is that the conventional application of the Cowan-Brown method to find the limiting current density, gives the second limiting current density. This current density is nearly two times higher than $i_{\lim }{ }^{1}$, which mainly determines the flux of phosphorus across the membrane.

Author Contributions: Conceptualization, N.P. and V.N.; Methodology, N.P.; Formal Analysis, S.M.; Investigation, O.R., K.T., E.M. and I.M.; Writing-Original Draft Preparation, N.P.; Writing-Review and Editing, V.N. and N.P.; Experimentation, O.R., K.T., E.M. and I.M.; Supervision, V.N. and N.P.; Project Administration, N.P.; Funding Acquisition, N.P. All authors approved the final article.

Funding: We are grateful to the Russian Science Foundation, grant No. 17-19-01486, for the financial support of this study. The authors thank the Core Facility "Environmental Analytical Center" of the Kuban State University (unique identifier RFMEFI59317X0008) for providing their equipment.

Conflicts of Interest: The authors declare no conflict of interest.

\section{References}

1. Paltrinieri, L.; Huerta, E.; Puts, T.; Van Baak, W.; Verver, A.B.; Sudhölter, E.J.R.; De Smet, L.C.P.M. Functionalized anion-exchange membranes facilitate electrodialysis of citrate and phosphate from model dairy wastewater. Environ. Sci. Technol. 2019, 53, 2396-2404. [CrossRef] [PubMed] 
2. Shi, L.; Xie, S.; Hu, Z.; Wu, G.; Morrison, L.; Croot, P.; Hu, H.; Zhan, X. Nutrient recovery from pig manure digestate using electrodialysis reversal: Membrane fouling and feasibility of long-term operation. J. Membr. Sci. 2019, 573, 560-569. [CrossRef]

3. Tran, A.T.K.; Zhang, Y.; Lin, J.; Mondal, P.; Ye, W.; Meesschaert, B.; Pinoy, L.; Van Der Bruggen, B. Phosphate pre-concentration from municipal wastewater by selectrodialysis: Effect of competing components. Sep. Purif. Technol. 2015, 141, 38-47. [CrossRef]

4. Zhang, Y.; Desmidt, E.; Van Looveren, A.; Pinoy, L.; Meesschaert, B.; Van Der Bruggen, B. Phosphate separation and recovery from wastewater by novel electrodialysis. Environ. Sci. Technol. 2013, 47, 5888-5895. [CrossRef] [PubMed]

5. Handojo, L.; Wardani, A.K.; Regina, D.; Bella, C.; Kresnowati, M.T.A.P.; Wenten, I.G. Electro-membrane processes for organic acid recovery. RSC Adv. 2019, 9, 7854-7869. [CrossRef]

6. El Rayess, Y.; Mietton-Peuchot, M. Membrane technologies in wine industry: An overview. Crit. Rev. Food Sci. 2016, 56, 2005-2020. [CrossRef] [PubMed]

7. Martín, J.; Díaz-Montaña, E.J.; Asuero, A.G. Recovery of anthocyanins using membrane technologies: A review. Crit. Rev. Anal. Chem. 2018, 48, 143-175. [CrossRef] [PubMed]

8. Galier, S.; Roux-de Balmann, H. The electrophoretic membrane contactor: A mass transfer-based methodology applied to the separation of whey proteins. Sep. Purif. Technol. 2011, 77, 237-244. [CrossRef]

9. Durand, R.; Fraboulet, E.; Marette, A.; Bazinet, L. Simultaneous double cationic and anionic molecule separation from herring milt hydrolysate and impact on resulting fraction bioactivities. Sep. Purif. Technol. 2019, 210, 431-441. [CrossRef]

10. Chandra, A.; Tadimeti, J.G.D.; Chattopadhyay, S. Transport hindrances with electrodialytic recovery of citric acid from solution of strong electrolytes. Chin. J. Chem. Eng. 2018, 26, 278-292. [CrossRef]

11. Suwal, S.; Rozoy, É.; Manenda, M.; Doyen, A.; Bazinet, L. Comparative study of in situ and ex situ enzymatic hydrolysis of milk protein and separation of bioactive peptides in an electromembrane reactor. ACS Sustain. Chem. Eng. 2017, 5, 5330-5340. [CrossRef]

12. Strathmann, H. Electrodialysis, a mature technology with a multitude of new applications. Desalination 2010, 264, 268-288. [CrossRef]

13. Fidaleo, M.; Moresi, M. Concentration of trisodium citrate by electrodialysis. J. Membr. Sci. 2013, 447, 376-386. [CrossRef]

14. Myles, T.D.; Grew, K.N.; Peracchio, A.A.; Chiu, W.K.S. Transient ion exchange of anion exchange membranes exposed to carbon dioxide. J. Power Sour. 2015, 296, 225-236. [CrossRef]

15. Ramirez, P.; Alcaraz, A.; Mafe, S.; Pellicer, J. pH and supporting electrolyte concentration effects on the passive transport of cationic and anionic drugs through fixed charge membranes. J. Membr. Sci. 1999, 161, 143-155. [CrossRef]

16. Sarapulova, V.; Nevakshenova, E.; Pismenskaya, N.; Dammak, L.; Nikonenko, V. Unusual concentration dependence of ion-exchange membrane conductivity in ampholyte-containing solutions: Effect of ampholyte nature. J. Membr. Sci. 2015, 479, 28-38. [CrossRef]

17. Andersen, M.B.; Rogers, D.M.; Mai, J.; Schudel, B.; Hatch, A.V.; Rempe, S.B.; Mani, A. Spatiotemporal $\mathrm{pH}$ dynamics in concentration polarization near ion-selective membranes. Langmuir 2014, 30, 7902-7912. [CrossRef]

18. Femmer, R.; Mani, A.; Wessling, M. Ion transport through electrolyte/polyelectrolyte multi-layers. Sci. Rep. 2015, 5, 1-12. [CrossRef]

19. Zabolotskii, V.I.; Gnusin, N.P.; El'nikova, L.F.; Blednykh, V.M. Exhaustive purification of amino acids by removal of mineral impurities by electrodialysis with ion-exchange membranes. J. App. Chem.-Ussr 1986, 59, 127-131.

20. Shaposhnik, V.A.; Eliseeva, T.V. Barrier effect during the electrodialysis of ampholytes. J. Membr. Sci. 1999, 161, 223-229. [CrossRef]

21. Eliseeva, T.V.; Shaposhnik, V.A. Effects of circulation and facilitated electromigration of amino acids in electrodialysis with ion-exchange membranes. Russ. J. Electrochem. 2000, 36, 64-67. [CrossRef]

22. Dufton, G.; Mikhaylin, S.; Gaaloul, S.; Bazinet, L. How electrodialysis configuration influences acid whey deacidification and membrane scaling. J. Dairy Sci. 2018, 101, 7833-7850. [CrossRef] [PubMed]

23. Rotta, E.H.; Bitencourt, C.S.; Marder, L.; Bernardes, A.M. Phosphorus recovery from low phosphate-containing solution by electrodialysis. J. Membr. Sci. 2019, 573, 293-300. [CrossRef] 
24. Franck-Lacaze, L.; Sistat, P.; Huguet, P.; Lapicque, F. Protonation and diffusion phenomena in poly(4-vinylpyridine)-based weak anion-exchange membranes. J. Membr. Sci. 2009, 340, 257-265. [CrossRef]

25. Koter, S.; Kultys, M. Modeling the electric transport of sulfuric and phosphoric acids through anion-exchange membranes. Sep. Purif. Technol. 2010, 73, 219-229. [CrossRef]

26. Kozmai, A.E.; Nikonenko, V.V.; Zyryanova, S.; Pismenskaya, N.D.; Dammak, L. A simple model for the response of an anion-exchange membrane to variation in concentration and $\mathrm{pH}$ of bathing solution. J. Membr. Sci. 2018, 567, 127-138. [CrossRef]

27. Vasil'eva, V.; Goleva, E.; Pismenskaya, N.; Kozmai, A.; Nikonenko, V. Effect of surface profiling of a cation-exchange membrane on the phenylalanine and $\mathrm{NaCl}$ separation performances in diffusion dialysis. Sep. Purif. Technol. 2019, 210, 48-59. [CrossRef]

28. Ueno, K.; Doi, T.; Nanzai, B.; Igawa, M. Selective transport of neutral amino acids across a double-membrane system comprising cation and anion exchange membranes. J. Membr. Sci. 2017, 537, 344-352. [CrossRef]

29. Ramírez, P.; Alcaraz, A.; Mafé, S. Modeling of amino acid electrodiffusion through fixed charge membranes. J. Coll. Interface Sci. 2001, 242, 164-173. [CrossRef]

30. Rybalkina, O.A.; Tsygurina, K.A.; Melnikova, E.D.; Pourcelly, G.; Nikonenko, V.V.; Pismenskaya, N.D. Catalytic effect of ammonia-containing species on water splitting during electrodialysis with ion-exchange membranes. Electrochim. Acta 2019, 299, 946-962. [CrossRef]

31. Belashova, E.D.; Pismenskaya, N.D.; Nikonenko, V.V.; Sistat, P.; Pourcelly, G. Current-voltage characteristic of anion-exchange membrane in monosodium phosphate solution. Modelling and experiment. J. Membr. Sci. 2017, 542, 177-185. [CrossRef]

32. Melnikova, E.D.; Pismenskaya, N.D.; Bazinet, L.; Mikhaylin, S.; Nikonenko, V.V. Effect of ampholyte nature on current-voltage characteristic of anion-exchange membrane. Electrochim. Acta 2018, 285, 185-191. [CrossRef]

33. Wang, X.; Zhang, X.; Wang, Y.; Du, Y.; Feng, H.; Xu, T. Simultaneous recovery of ammonium and phosphorus via the integration of electrodialysis with struvite reactor. J. Membr. Sci. 2015, 490, 65-71. [CrossRef]

34. Ward, A.J.; Arola, K.; Thompson Brewster, E.; Mehta, C.M.; Batstone, D.J. Nutrient recovery from wastewater through pilot scale electrodialysis. Water Res. 2018, 135, 57-65. [CrossRef] [PubMed]

35. Yang, Y.; Lin, L.; Tse, L.K.; Dong, H.; Yu, S.; Hoffmann, M.R. Membrane-separated electrochemical latrine wastewater treatment. Environ. Sci. Water Res. Technol. 2019, 5, 51-59. [CrossRef]

36. Shi, L.; Hu, Y.; Xie, S.; Wu, G.; Hu, Z.; Zhan, X. Recovery of nutrients and volatile fatty acids from pig manure hydrolysate using two-stage bipolar membrane electrodialysis. Chem. Eng. J. 2018, 334, 134-142. [CrossRef]

37. Ebbers, B.; Ottosen, L.M.; Jensen, P.E. Electrodialytic treatment of municipal wastewater and sludge for the removal of heavy metals and recovery of phosphorus. Electrochim. Acta 2015, 181, 90-99. [CrossRef]

38. Geng, Y.-K.; Wang, Y.; Pan, X.-R.; Sheng, G.-P. Electricity generation and in situ phosphate recovery from enhanced biological phosphorus removal sludge by electrodialysis membrane bioreactor. Bioresour. Technol. 2018, 247, 471-476. [CrossRef]

39. De Paepe, J.; Lindeboom, R.E.F.; Vanoppen, M.; De Paepe, K.; Demey, D.; Coessens, W.; Lamaze, S.; Verliefde, A.R.D.; Clauwaert, P.; Vlaeminck, S.E. Refinery and concentration of nutrients from urine with electrodialysis enabled by upstream precipitation and nitrification. Water Res. 2018, 144, 76-86. [CrossRef]

40. Gallya, C.R.; Benvenutia, T.; Trindade, C.M.; Rodrigues, M.A.S.; Zoppas-Ferreira, J.; Pérez-Herranz, V.; Bernardes, A.M. Electrodialysis for the tertiary treatment of municipal wastewater: Efficiency of ion removal and ageing of ion exchange membranes. J. Environ. Chem. Eng. 2018, 3, 5855-5869. [CrossRef]

41. Weinertova, K.; Honorato, R.S.; Stranska, E.; Nedela, D. Comparison of heterogeneous anion-exchanges for nitrate ion removal from mixed salt solution. Chem. Pap. 2018, 72, 469-478. [CrossRef]

42. Paltrinieri, L.; Poltorak, L.; Chu, L.; Puts, T.; van Baak, W.; Sudhölter, E.J.R.; de Smet, L.C.P.M. Hybrid polyelectrolyte-anion exchange membrane and its interaction with phosphate. React. Funct. Polym. 2018, 133, 126-135. [CrossRef]

43. Cowan, D.Q.; Brown, I.W. Effect of turbulence in limiting current in electrodialysis cell. Ind. Eng. Chem. 1959, 51, 1445-1449. [CrossRef]

44. Chandra, A.; Tadimeti, J.G.D.; Bhuvanesh, E.; Pathiwada, D.; Chattopadhyay, S. Switching selectivity of carboxylic acids and associated physic-chemical changes with $\mathrm{pH}$ during electrodialysis of ternary mixtures. Sep. Purif. Technol. 2018, 193, 327-344. [CrossRef] 
45. Lopatkova, G.Y.; Volodina, E.I.; Pis'menskaya, N.D.; Fedotov, Y.A.; Cot, D.; Nikonenko, V.V. Effect of chemical modification of ion-exchange membrane MA-40 on its electrochemical characteristics. Russ. J. Electrochem. 2006, 42, 847-854. [CrossRef]

46. Zabolotskii, V.I.; Bugakov, V.V.; Sharafan, M.V.; Chermit, R.K. Transfer of electrolyte ions and water dissociation in anion-exchange membranes under intense current conditions. Russ. J. Electrochem. 2012, 48, 650-659. [CrossRef]

47. Pismenskaya, N.D.; Pokhidnia, E.V.; Pourcelly, G.; Nikonenko, V.V. Can the electrochemical performance of heterogeneous ion-exchange membranes be better than that of homogeneous membranes? J. Membr. Sci. 2018, 566, 54-68. [CrossRef]

48. Rubinstein, I.; Zaltzman, B. Equilibrium electro-osmotic instability in concentration polarization at a perfectly charge-selective interface. Phys. Rev. Fluids 2017, 2, 093702. [CrossRef]

49. Pismenskaya, N.D.; Nikonenko, V.V.; Belova, E.I.; Lopatkova, G.Y.; Sistat, P.; Pourcelly, G.; Larshe, K. Coupled convection of solution near the surface of ion exchange membranes in intensive current regimes. Russ. J. Electrochem. 2007, 43, 307-327. [CrossRef]

50. Kniaginicheva, E.; Pismenskaya, N.; Melnikov, S.; Belashova, E.; Sistat, P.; Cretin, M.; Nikonenko, V. Water splitting at an anion-exchange membrane as studied by impedance spectroscopy. J. Membr. Sci. 2015, 496, 78-83. [CrossRef]

51. Kharkats, Y.I. The mechanism of supralimiting currents at ion-exchange membrane electrolyte interfaces. Sov. Electrochem. 1985, 21, 917-920.

52. Urtenov, M.; Kirillova, E.; Seidova, N.; Nikonenko, V. Decoupling of the Nernst-Planck and Poisson equations. Application to a membrane system at overlimiting currents. J. Phys. Chem. B 2007, 111, 14208-14222. [CrossRef] [PubMed]

53. Nikonenko, V.V.; Mareev, S.A.; Pis'menskaya, N.D.; Uzdenova, A.M.; Kovalenko, A.V.; Urtenov, M.K.; Pourcelly, G. Effect of electroconvection and its use in intensifying the mass transfer in electrodialysis. Russ. J. Electrochem. 2017, 53, 1122-1144. [CrossRef]

54. Rybalkina, O.A.; Melnikova, E.D.; Pismenskiy, A.V. Influence of gravitational convection on current-voltage characteristics of an electromembrane stack in sodium dihydrogen phosphate solution. Petrol. Chem. 2018, 58, 114-120. [CrossRef]

55. Rubinstein, S.M.; Manukyan, G.; Staicu, A.; Rubinstein, I.; Zaltzman, B.; Lammertink, R.G.H.; Mugele, F.; Wessling, M. Direct observation of a nonequilibrium electro-osmotic instability. Phys. Rev. Lett. 2008, 101, 236101. [CrossRef]

56. Mishchuk, N.A. Concentration polarization of interface and non-linear electrokinetic phenomena. Adv. Coll. Interface Sci. 2010, 160, 16. [CrossRef]

57. Simons, R. Electric field effects on proton transfer between ionizable groups and water in ion exchange membranes. Electrochim. Acta 1984, 29, 151-158. [CrossRef]

58. Simons, R. Strong electric field effects on proton transfer between membrane-bound amines and water. Nature 1979, 280, 824-826. [CrossRef]

59. Zabolotskii, V.I.; Shel'deshov, N.V.; Gnusin, N.P. Dissociation of water molecules in systems with ion-exchange membranes. Russ. Chem. Rev. 1988, 57, 801-808. [CrossRef]

60. Slouka, Z.; Senapati, S.; Yan, Y.; Chang, H.-C. Charge inversion, water splitting, and vortex suppression due to DNA sorption on ion-selective membranes and their ion-current signatures. Langmuir 2012, 29, 8275-8283. [CrossRef]

61. Lide, D.R. Handbook of Chemistry and Physics; CRC Press: New York, NY, USA, 1995.

62. McMurry, J. Fundamentals of Organic Chemistry; Brooks/Cole; Cengage Learning: Belmont, NJ, USA, 2010.

63. Mizutani, Y. Structure of ion exchange membranes. J. Membr. Sci. 1990, 49, 121-144. [CrossRef]

64. Doi, S.; Yasukawa, M.; Kakihana, Y.; Higa, M. Alkali attack on anion exchange membranes with PVC backing and binder: Effect on performance and correlation between them. J. Membr. Sci. 2019, 573, 85-96. [CrossRef]

65. Doi, S.; Kinoshita, M.; Yasukawa, M.; Higa, M. Alkali attack on anion exchange membranes with PVC backing and binder: II prediction of electrical and mechanical performances from simple optical analyses. Membranes 2018, 8, 133. [CrossRef] [PubMed]

66. Güler, E.; van Baak, W.; Saakes, M.; Nijmeijer, K. Monovalent-ion-selective membranes for reverse electrodialysis. J. Membr. Sci. 2014, 455, 254-270. [CrossRef] 
67. Mareev, S.A.; Butylskii, D.Y.; Pismenskaya, N.D.; Larchet, C.; Dammak, L.; Nikonenko, V.V. Geometric heterogeneity of homogeneous ion-exchange Neosepta ${ }^{\circledR}$ membranes. J. Membr. Sci. 2018, 563, 768-776. [CrossRef]

68. Ion Exchange Membranes for Water Purification. Brochure of Fujifilm Membrane Technology. Version number 1.0. 2018. Available online: https://www.fujifilmmembranes.com/water-membranes/ion-exchangemembranes (accessed on 1 July 2019).

69. Rabolt, J.F.; Lee, K.H.; Givens, S.R. Method of Solution Preparation of Polyolefin Class Polymers for Electrospinning Processing Included. U.S. Patent 8,083,983 B2, 27 December 2011.

70. Zhu, Y.; Ahmad, M.; Yang, L.; Misovich, M.; Yaroshchuk, A.; Bruening, M.L. Adsorption of polyelectrolyte multilayers imparts high monovalent/divalent cation selectivity to aliphatic polyamide cation-exchange membranes. J. Membr. Sci. 2017, 537, 177-185. [CrossRef]

71. Zhang, W.; Ma, J.; Wang, P.; Wang, Z.; Shi, F.; Liu, H. Investigations on the interfacial capacitance and the diffusion boundary layer thickness of ion exchange membrane using electrochemical impedance spectroscopy. J. Membr. Sci. 2016, 502, 37-47. [CrossRef]

72. Antheunis, H.; Hessing, J.; Van Berchum, B. Curable Compositions and Membranes. U.S. Patent 8,968,965 B2, 3 March 2015.

73. Berezina, N.P.; Timofeev, S.V.; Kononenko, N.A. Effect of conditioning techniques of perfluorinated sulphocationic membranes on their hydrophylic and electrotransport properties. J. Membr. Sci. 2002, 209, 509-518. [CrossRef]

74. Volkov, A.I.; Zharskii, I.M. Comprehensive Chemical Handbook; Modern School: Moscow, Russia, 2005.

75. Robinson, R.A.; Stokes, R.H. Electrolyte Solutions; Butterworths: London, UK, 1959.

76. Belova, E.I.; Lopatkova, G.Y.; Pismenskaya, N.D.; Nikonenko, V.V.; Larchet, C.; Pourcelly, G. Effect of anion-exchange membrane surface properties on mechanisms of overlimiting mass transfer. J. Phys. Chem. B 2006, 110, 13458-13469. [CrossRef]

77. Rösler, H.-W.; Maletzki, F.; Staude, E. A numerical study of the hydrodynamic stable concentration boundary layers in a membrane system under microgravitational conditions. J. Membr. Sci. 1992, 72, 171-179. [CrossRef]

78. Newman, J.S. Electrochemical Systems; Prentice Hall: Englewood Cliffs, NY, USA, 1973.

79. Sheldeshov, N.V.; Ganych, V.V.; Zabolotsky, V.I. Transport numbers of salt ions and water dissociation products in cation and anion-exchange membranes. Sov. Electrochem. 1991, 23, 11-15.

80. Laktionov, E.V.; Pismenskaya, N.D.; Nikonenko, V.V.; Zabolotsky, V.I. Method of electrodialysis stack testing with the feed solution concentration regulation. Desalination 2003, 152, 101-116. [CrossRef]

81. Helfferich, F.G. Ion Exchange; McGraw-Hill: New York, NY, USA, 1962; ASIN B0000CLGWI.

82. Kwak, R.; Guan, G.; Peng, W.K.; Han, J. Microscale electrodialysis: Concentration profiling and vortex visualization. Desalination 2013, 308, 138-146. [CrossRef]

83. Mareev, S.A.; Butylskii, D.Y.; Kovalenko, A.V.; Petukhova, A.V.; Pismenskaya, N.D.; Dammak, L.; Larchet, C.; Nikonenko, V.V. Accounting for the concentration dependence of electrolyte diffusion coefficient in the Sand and the Peers equations. Electrochim. Acta 2016, 195, 85-93. [CrossRef]

84. Zabolotsky, V.I.; Nikonenko, V.V. Effect of structural membrane inhomogeneity on transport properties. J. Membr. Sci. 1993, 79, 181-198. [CrossRef]

(C) 2019 by the authors. Licensee MDPI, Basel, Switzerland. This article is an open access article distributed under the terms and conditions of the Creative Commons Attribution (CC BY) license (http://creativecommons.org/licenses/by/4.0/). 